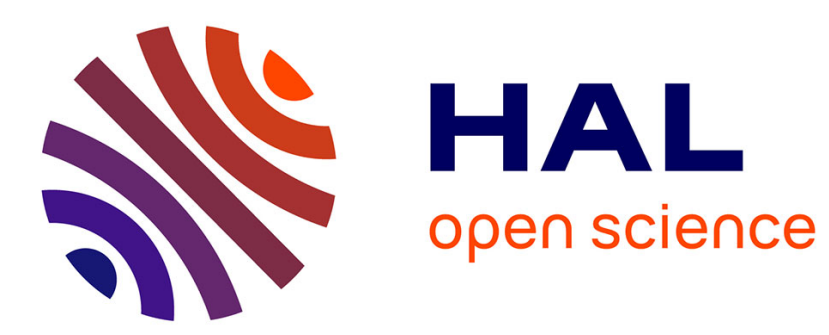

\title{
An empirical estimate of the Southern Ocean air-sea CO2 flux
}

Ben I. Mcneil, Nicolas Metzl, Robert M. Key, Richard J. Matear, Antoine Corbière

\section{- To cite this version:}

Ben I. Mcneil, Nicolas Metzl, Robert M. Key, Richard J. Matear, Antoine Corbière. An empirical estimate of the Southern Ocean air-sea CO2 flux. Global Biogeochemical Cycles, 2007, 21 (3), pp.GB3011. 10.1029/2007GB002991 . hal-00168173

\section{HAL Id: hal-00168173 https://hal.science/hal-00168173}

Submitted on 29 Oct 2021

HAL is a multi-disciplinary open access archive for the deposit and dissemination of scientific research documents, whether they are published or not. The documents may come from teaching and research institutions in France or abroad, or from public or private research centers.
L'archive ouverte pluridisciplinaire HAL, est destinée au dépôt et à la diffusion de documents scientifiques de niveau recherche, publiés ou non, émanant des établissements d'enseignement et de recherche français ou étrangers, des laboratoires publics ou privés. 


\title{
An empirical estimate of the Southern Ocean air-sea $\mathrm{CO}_{2}$ flux
}

\author{
Ben I. McNeil, ${ }^{1}$ Nicolas Metzl, ${ }^{2}$ Robert M. Key, ${ }^{3}$ Richard J. Matear, ${ }^{4}$ \\ and Antoine Corbiere ${ }^{2}$ \\ Received 10 April 2007; accepted 25 May 2007; published 18 August 2007.
}

[1] Despite improvements in our understanding of the Southern Ocean air-sea flux of $\mathrm{CO}_{2}$, discrepancies still exist between a variety of differing ocean/atmosphere methodologies. Here we employ an independent method to estimate the Southern Ocean air-sea flux of $\mathrm{CO}_{2}$ that exploits all available surface ocean measurements for dissolved inorganic carbon (DIC) and total alkalinity (ALK) beyond 1986. The DIC concentrations were normalized to the year 1995 using coinciding CFC measurements in order to account for the anthropogenic $\mathrm{CO}_{2}$ signal. We show that independent of season, surface-normalized DIC and ALK can be empirically predicted to within $\sim 8 \mu \mathrm{mol} / \mathrm{kg}$ using standard hydrographic properties. The predictive equations were used in conjunction with World Ocean Atlas (2001) climatologies to give a first estimate of the annual cycle of DIC and ALK in the surface Southern Ocean. These seasonal distributions will be very useful in both validating biogeochemistry in general circulation models and for use in situ biological studies within the Southern Ocean. Using optimal $\mathrm{CO}_{2}$ dissociation constants, we then estimate an annual cycle of $\mathrm{pCO}_{2}$ and associated net air-sea $\mathrm{CO}_{2}$ flux. Including the effects of sea ice, we estimate a Southern Ocean $\left(>50^{\circ} \mathrm{S}\right) \mathrm{CO}_{2}$ sink of $0.4 \pm 0.25 \mathrm{Pg} \mathrm{C} / \mathrm{yr}$. Our analysis also indicates a substantial $\mathrm{CO}_{2}$ sink of $1.1 \pm 0.6 \mathrm{Pg} \mathrm{C} / \mathrm{yr}$ within the sub-Antarctic zone $\left(40^{\circ} \mathrm{S}-50^{\circ} \mathrm{S}\right)$, associated with strong cooling and high winds. Our results imply the Southern Ocean $\mathrm{CO}_{2}$ flux south of $50^{\circ} \mathrm{S}$ to be very similar to those found by Takahashi et al. (2002), but on the higher end of a range of atmospheric/oceanic $\mathrm{CO}_{2}$ inversion methodologies. This paper estimates for the first time basic seasonal carbon cycle parameters within the circumpolar Southern Ocean, which have up to now been extremely difficult to measure and sparse. The application of such an empirical technique using more widely available hydrographic parameters in the Southern Ocean provides an important independent estimate to not only $\mathrm{CO}_{2}$ uptake, but also for other future biogeochemical studies. Refining and testing these empirical methods with new carbon measurements will be important to further reduce uncertainties and extend our understanding of Southern Ocean $\mathrm{CO}_{2}$ dynamics.

Citation: McNeil, B. I., N. Metzl, R. M. Key, R. J. Matear, and A. Corbiere (2007), An empirical estimate of the Southern Ocean air-sea $\mathrm{CO}_{2}$ flux, Global Biogeochem. Cycles, 21, GB3011, doi:10.1029/2007GB002991.

\section{Introduction and Background}

[2] One of the most pressing issues in understanding the present-day carbon budget is determining the role of the Southern Ocean. A discrepancy currently exists between models and observations in estimating the Southern Ocean $\mathrm{CO}_{2}$ air-sea flux. General ocean circulation models [Matear

\footnotetext{
${ }^{1}$ Climate Change Research Centre, School of Mathematics, University of New South Wales, Sydney, New South Wales, Australia.

${ }^{2}$ Laboratoire d'Océanographie et du Climati Expérimentations et Approches Numériques (LOCEAN), UMR 7159, CNRS, Institut Pierre Simon Laplace, Universite Pierre et Marie Curie, Paris, France.

${ }^{3}$ Program in Atmosphere and Ocean Sciences, Department of Geosciences, Princeton University, Princeton, New Jersey, USA.

${ }^{4}$ Division of Marine Research, CSIRO, Hobart, Tasmania, Australia.

Copyright 2007 by the American Geophysical Union. 0886-6236/07/2007GB002991
}

and Hirst, 1999], atmospheric inverse models [Gurney et al., 2002; Patra et al., 2005]; oceanic inverse models [Gloor et al., 2003] all suggest the Southern Ocean (south of $50^{\circ} \mathrm{S}$ ) maintains a contemporary $\mathrm{CO}_{2}$ sink of 0.1 to $0.5 \mathrm{PgC} / \mathrm{yr}$, while oceanic $\mathrm{pCO}_{2}$ measurements suggest a $\mathrm{CO}_{2}$ sink of 0.5 to $0.7 \mathrm{PgC} / \mathrm{yr}$ [Takahashi et al., 2002] (hereinafter referred to as T02). It is important to note however that the original manuscript from T02 used the 0.995 sigma winds instead of the $10 \mathrm{~m}$ winds which was required in the gas transfer relationships. Since the paper was published T02 have revised their global air-sea fluxes using the $10 \mathrm{~m}$ wind speeds (see http://www.ldeo.columbia.edu/res/pi/ $\mathrm{CO}_{2} /$ carbondioxide/pages/air_sea_flux_rev1.html). The corrected flux estimates (herein referre $\bar{d}$ to as T02corr) suggest a Southern Ocean sink of $\sim 0.35-0.45 \mathrm{PgC} / \mathrm{yr}$ south of $50^{\circ} \mathrm{S}$. Atmospheric inverse modeling predictions are subject to biases due to sparse regional atmospheric $\mathrm{CO}_{2}$ record in 
the Southern Ocean and possibly unrealistic Southern Hemispheric atmospheric transport [Gurney et al., 2002]. The $\mathrm{pCO}_{2}$ observational network accumulated by $\mathrm{T} 02$ in the Southern Ocean is subject to sparse sampling and measurement bias since most measurements have been taken during the Austral summer. In order to fill the gaps throughout the year, surface circulation vectors from a three-dimensional ocean general circulation model were used. The seasonal biases in the coverage of the data and the introduction of a model adds uncertainty to the air-sea flux of $\mathrm{CO}_{2}$ in the Southern Ocean via direct $\mathrm{pCO}_{2}$ measurements.

[3] Here we present an independent method for estimating Southern Ocean $\mathrm{CO}_{2}$ uptake that exploits empirical extrapolations of surface dissolved inorganic carbon (DIC) and total alkalinity (ALK) from which $\mathrm{pCO}_{2}$ can be calculated. Although the methodology does not use $\mathrm{pCO}_{2}$ directly, the advantages to using DIC and ALK are two-fold. First, DIC and ALK are mostly measured using discrete CTD Rosette samples upon which a multitude of other parameters are also measured including temperature, salinity, oxygen and nutrients. Even though DIC and ALK are sampled sporadically in space and time, direct relationships with these other standard hydrographic parameters can be determined. There are at least ten times as many hydrographic measurements carbon, and these hydrographic data are explicitly used to estimate a seasonal/annual cycle for DIC and ALK thereby reducing the spatiotemporal biases. Continuous $\mathrm{pCO}_{2}$ measurements generally do not have corresponding biogeochemical measurements. Secondly, DIC/ALK is simpler to interpolate/extrapolate. Since the correlation length/timescales are longer than for $\mathrm{pCO}_{2}$, they are less sensitive to small-scale variability. The main disadvantage in our approach is the requirement to calculate $\mathrm{pCO}_{2}$ using $\mathrm{CO}_{2}$ dissociation constants, however a new analysis of over 1500 measurements provides considerable insight into the uncertainty from this calculation.

[4] The World Ocean Circulation Experiment (WOCE) and Joint Global Ocean Flux Study (JGOFS) measuring programs for carbon (1991-1998) were the most extensive attempt to understand the global oceanic carbon cycle. Even so, carbon sampling in the Southern Ocean was sporadic in both space and time. Considering that it is currently infeasible to implement a Southern Ocean carbon measuring program dense enough to cover seasonal variations, it is important to explore empirical relationships that could be used to predict carbon parameters via more widely available properties such as temperature, salinity and nutrients.

[5] Oceanic dissolved inorganic carbon (DIC) and total alkalinity (ALK) are carbon measurements that are best suited to empirical relationships since during WOCE/ JGOFS they are taken on discrete bottles with coinciding temperature, salinity, nutrients and oxygen measurements. Wallace [1995] introduced the concept of using multiple linear regression to predict DIC using various standard hydrographic measurements within the interior of the ocean. Goyet and Davis [1997] used this methodology to predict DIC from temperature, salinity and oxygen measurements below $500 \mathrm{~m}$ in the North Atlantic. A multiple linear regression was used to develop an equation for DIC and resulted in a standard error of about $7 \mu \mathrm{mol} / \mathrm{kg}$ using DIC measurements from the mid-1980s from the TTO program. Lee et al. [2000b] extended this approach to the global surface ocean using DIC measurements from the OACES program (late 1980s) and some of the WOCE program (early 1990s). By using temperature and nitrate they found DIC to be predicted to within about $8 \mu \mathrm{mol} / \mathrm{kg}$ and ALK to within about $15 \mu \mathrm{mol} / \mathrm{kg}$ on an area-weighted average. Although these studies highlight the potential use of empirical techniques to predict DIC on large scales, the effects of anthropogenic $\mathrm{CO}_{2}$ uptake was not included and only a sparse amount of carbon data could be used for the Southern Ocean. The storage of anthropogenic $\mathrm{CO}_{2}$ in the Southern Ocean (south of $40^{\circ} \mathrm{S}$ ) has been shown to be up to $0.8 \mu \mathrm{mol} / \mathrm{kg} / \mathrm{yr}$ [McNeil et al., 2001], which would imply a DIC change of up to about $9 \mu \mathrm{mol} / \mathrm{kg}$ over the period used by Lee et al. Considering the winter to summer changes of DIC within the Southern Ocean to be of the order of $20-$ $30 \mu \mathrm{mol} / \mathrm{kg}$, the bias due to inadequately correcting for the anthropogenic $\mathrm{CO}_{2}$ increase is not negligible. Recently, Bates et al. [2006] used a linear empirical technique in the Indian Ocean to estimate air-sea fluxes and net community production. By using carbon measurements taken between December 1994 and January 1996, avoids the previous problem of requiring to correct for the anthropogenic $\mathrm{CO}_{2}$ signal since over 1 year the changes to DIC would be particularly small. However, if one uses carbon data collected over a 10 year period, then correcting for the anthropogenic $\mathrm{CO}_{2}$ signal is warranted.

[6] Our methodology (and the structure of this paper) to estimate the air-sea $\mathrm{CO}_{2}$ flux in the Southern Ocean follows a stepwise procedure.

[7] 1. A predictive empirical relationship for DIC and ALK is developed that uses all available carbon measurements over the past two decades where DIC has been normalized to a common year (1995) using CFC measurements.

[8] 2. The predictive relationship is exploited by using all available hydrographic properties from the World Ocean Atlas 2001 in order to estimate an annual cycle of DIC and ALK for the year 1995.

[9] 3. We then use over 1500 new measurements with corresponding DIC, ALK and $\mathrm{pCO}_{2}$ to determine the optimal $\mathrm{CO}_{2}$ dissociation constants to use for our study.

[10] 4. The annual cycle of $\mathrm{pCO}_{2}$ for 1995 is then calculated using the optimal $\mathrm{CO}_{2}$ dissociation constants and compared to the $\mathrm{pCO}_{2}$ climatologies of $\mathrm{T} 02$.

[11] 5. The final step was to use global wind products and gas exchange velocities to estimate a net uptake of $\mathrm{CO}_{2}$ in the Southern Ocean including the effects of sea ice. A careful uncertainty analysis precludes a final estimate of $\mathrm{CO}_{2}$ uptake in the Southern Ocean and a comparison to other independent results.

\section{Data and Consistency}

[12] For this study we use all available DIC measurements that have con-current temperature, salinity, oxygen and nutrient observations south of $40^{\circ} \mathrm{S}$ since 1986 (Figure 1). The cruises used cover both Austral summer and winter in the Southern Ocean with about $68 \%$ of samples being in the 


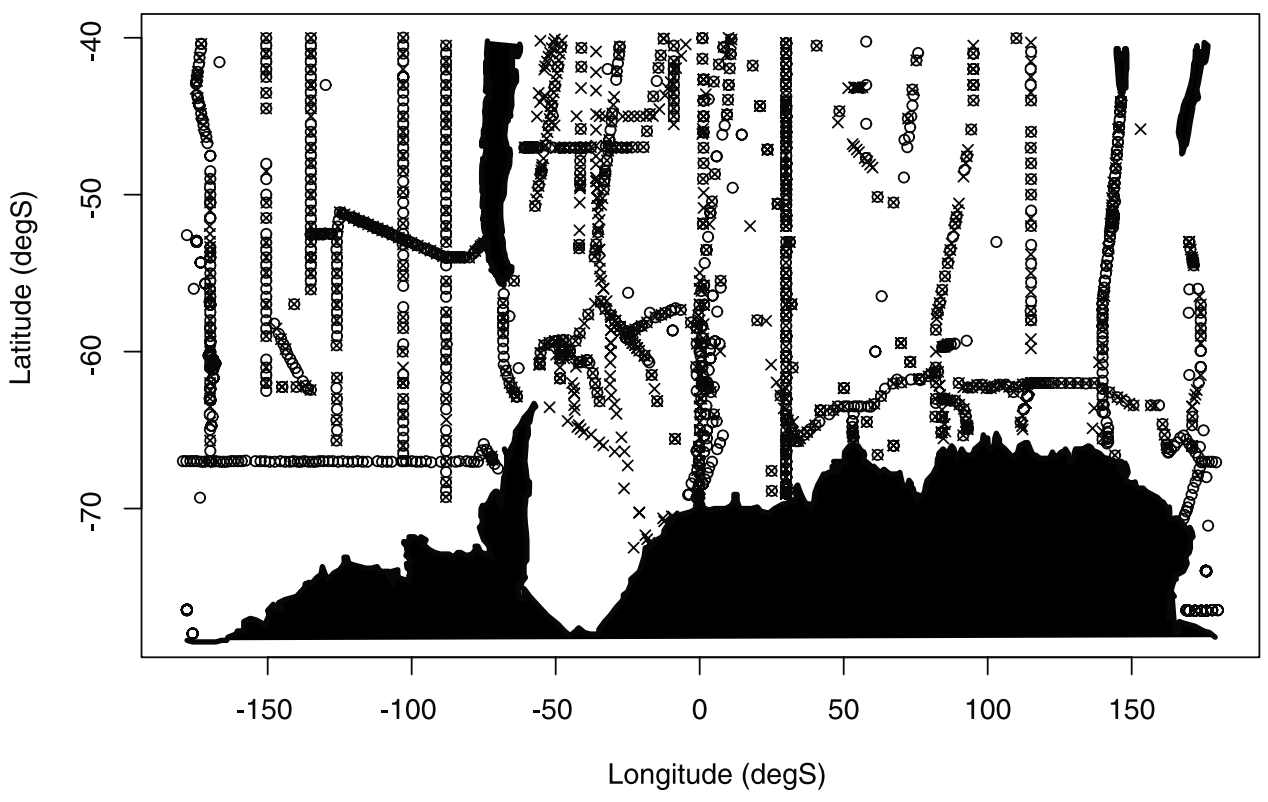

Figure 1. Surface carbon measurements used in the study. Crosses denote locations of all DIC measurements while circles denote ALK measurements.

period between November and March. A recent synthesis of global oceanic carbon measurements has been published [Key et al., 2004] along with its public availability (http:// cdiac.ornl.gov/oceans/glodap/Glodap_home.htm). Measurements of DIC and ALK made throughout WOCE and JGOFS have undergone careful checks for consistency [Johnson et al., 1998; Lamb et al., 2002] along with comparison to Certified Reference Materials that have been made available [Dickson, 2001].

\section{Methodology}

\subsection{Empirical Prediction of Surface DIC and ALK Concentrations}

[13] Over the period in which DIC measurements were collected (1986-1997), atmospheric $\mathrm{CO}_{2}$ increased from 345 to $362 \mathrm{ppm}$ via anthropogenic $\mathrm{CO}_{2}$ emissions. As a result the DIC concentration in the Southern Ocean will have changed depending on the location and year it was sampled owing to storage of anthropogenic $\mathrm{CO}_{2}$. The first step in our approach was therefore to normalize the DIC data to a common year (1995) to account for this. For the normalization we use the $\mathrm{CFC}$-age technique which is described in detail elsewhere [Matear et al., 2003; McNeil et al., 2003]. On the basis of knowledge of the surface alkalinity concentrations and atmospheric $\mathrm{CO}_{2}$ history, the changes in DIC between two time periods ( $\mathrm{t} 1$ and $\mathrm{t}_{2}$ ) can be determined via

$$
\begin{aligned}
D I C\left(t_{2}\right)-D I C\left(t_{1}\right)= & D I C_{e q}\left(S, T, A L K_{0}, f C O_{2}\left(t_{2}-\tau\right)\right) \\
& -D I C_{e q}\left(S, T, A L K_{0}, f C O_{2}\left(t_{1}-\tau\right)\right),
\end{aligned}
$$

where DIC $\left(t_{2}\right)$ - DIC $\left(t_{1}\right)$ is the change in DIC from year $\left(t_{1}\right)$ to year $\left(t_{2}\right)$ due to the anthropogenic $\mathrm{CO}_{2}$ uptake, $\mathrm{DIC}_{\mathrm{eq}}$ is the equilibrium concentration when last at the surface ocean with a given atmospheric $\mathrm{CO}_{2}$ concentration $\left(\mathrm{fCO}_{2}\right)$, $\mathrm{T}$ is the temperature, $\mathrm{S}$ is the salinity, $\mathrm{ALK}_{0}$ is the preformed alkalinity and $\tau$ is the water mass age in years. Under steady state conditions $\triangle \mathrm{DIC}$ ranged from $0-10 \mu \mathrm{mol} / \mathrm{kg}$. These estimates were applied to the DIC data in order to normalize all data to the nominal year of 1995 .

[14] With surface DIC measurements normalized to a common year, a linear least squares regression was conducted using various independent parameters as predictors. Multiple linear regression (MLR) has been widely used to account for large-scale variations in oceanic DIC [Bates et al., 2006; McNeil et al., 2001; Slansky et al., 1996; Wallace, 1995]. The regression equation for DIC is represented by: $D I C_{o b s}=\alpha_{0}+\sum_{i=1}^{n} \alpha_{i} P_{i}+\varepsilon_{i}$, where $\alpha_{\mathrm{i}}$ are the partial regression coefficients for $n$ independent parameters $\left(P_{i}\right)$, $\alpha_{0}$ is the intercept and $\varepsilon_{\mathrm{I}}$ are the residuals. Each regression was applied to the upper $55 \mathrm{~m}$ of data south of $40^{\circ} \mathrm{S}$. Table 1 shows the outcome of the MLR. The "best" regression was chosen by maximizing the adjusted coefficient of determination $\left(\mathrm{R}^{2}\right)$ while minimizing the standard error of the fit. As DIC is a nonconservative parameter dependent on biological processes, the addition of nonconservative parameters including $\mathrm{O}_{2}, \mathrm{NO} 3$ and $\mathrm{SiO} 4$ improves the fit progressively (Table 1). The final resulting fit for DIC uses 5 parameters $\left(\mathrm{T}, \mathrm{Sal}, \mathrm{O}_{2}, \mathrm{NO}_{3}\right.$ and $\left.\mathrm{SiO}_{4}\right)$ with a standard error of $\sim 8 \mu \mathrm{mol} / \mathrm{kg}$ and an adjusted $\mathrm{R}^{2}$ of 0.98 (Figure 2). Not including a correction for anthropogenic $\mathrm{CO}_{2}$ increased the uncertainty only slightly (Table 1 ). Without the need for correcting the anthropogenic $\mathrm{CO}_{2}$ signal via coinciding CFC measurements makes available an additional 1700 DIC measurements for use. The larger number of available DIC samples will partially offset the added uncertainty of not including a correction for anthropogenic $\mathrm{CO}_{2}$, however without correcting for anthropogenic $\mathrm{CO}_{2}$ increased the 
Table 1. Results of the Multiple Linear Regression for DIC in the Surface Southern Ocean

\begin{tabular}{|c|c|c|c|c|c|c|c|c|c|}
\hline$y$-int & $\begin{array}{c}\text { Temperature, } \\
{ }^{\circ} \mathrm{C}\end{array}$ & Sal & $\begin{array}{c}\mathrm{O}_{2}, \\
\mu \mathrm{mol} / \mathrm{kg}\end{array}$ & $\begin{array}{c}\mathrm{N}, \\
\mu \mathrm{mol} / \mathrm{kg}\end{array}$ & $\begin{array}{c}\mathrm{P}, \\
\mu \mathrm{mol} / \mathrm{kg}\end{array}$ & $\begin{array}{c}\text { Sil, } \\
\mu \mathrm{mol} / \mathrm{kg}\end{array}$ & $\mathrm{R}_{2}$ & $\begin{array}{c}\text { Standard } \\
\text { Error, } \\
\mu \mathrm{mol} / \mathrm{kg}\end{array}$ & $\mathrm{n}$ \\
\hline 2136.5 & -7.4 & - & - & 1 & - & - & 0.9 & 16 & 1035 \\
\hline 353.4 & -6.8 & 51.1 & - & 2.9 & - & - & 0.97 & 9.2 & 1034 \\
\hline 908.9 & -9.3 & 36.6 & - & - & - & 0.2 & 0.96 & 10.9 & 1034 \\
\hline 743.7 & -8.3 & 42.7 & -0.3 & 2.7 & - & - & 0.97 & 8.6 & 1033 \\
\hline 444.2 & -6.8 & 48.2 & - & - & 45.9 & - & 0.97 & 9 & 1034 \\
\hline 580.8 & -5.2 & 43.9 & - & 3.1 & - & 0.3 & 0.97 & 8.5 & 1033 \\
\hline 687.9 & -7.8 & 43.7 & -0.2 & 2 & 13.7 & - & 0.97 & 8.5 & 1032 \\
\hline $883.9^{\mathrm{a}}$ & -6.6 & 37.7 & -0.3 & 2.9 & - & 0.3 & 0.98 & 8 & 1032 \\
\hline 817 & -6 & 38.7 & -0.2 & 2 & 17.7 & 0.3 & 0.98 & 8 & 1031 \\
\hline $871^{\mathrm{b}}$ & -5.6 & 38.6 & -0.4 & 4.4 & - & 0.2 & 0.96 & 9.8 & 2785 \\
\hline
\end{tabular}

uncertainty by $2 \mu \mathrm{mol} / \mathrm{kg}$ (Table 1 ), although the empirical fit itself changed minorly. The addition of phosphate as an independent parameter did not improve the fit significantly owing to the high covariance with nitrate. To investigate the seasonal dependence we also separated Austral summer (November-March) and Austral winter (April-October) data and found little change in the DIC fit (Figure 2). DIC measurements taken over different years may also have a discernible interannual signal. For example, Jabaud-Jan et al. [2004] show signals of DIC interannual variability in the South Indian of $\sim 5-10 \mu \mathrm{mol} / \mathrm{kg}$. They found that these variations were mostly controlled by changes in primary production. The MLR methodology used here will average these interannual variations, especially given the span of time when the DIC measurements were collected (1986-1997).

[15] Carbon dynamics and variability are due to three processes: mixing, air-sea $\mathrm{CO}_{2}$ exchange and biological production. Ideally the parameters used to empirically predict DIC need to adequately capture the variability induced by these processes. Temperature and salinity are important since they characterize the large-scale physical oceanographic structure of the surface Southern Ocean. Oxygen and nutrients are controlled by mixing and biological production, but oxygen contains an air-sea exchange signature and therefore these properties contribute to the predictive capabilities of the fit for DIC. One of the main assumptions involved in multiple linear regression is that the independent parameters are linearly capable of predicting the dependent parameter (DIC). If this assumption is correct then the $\varepsilon_{\mathrm{I}}$ should be normally (Gaussian) distributed. Additionally, there should be no clear relationship between the residuals and any omitted independent parameter. This would indicate either biases in the measurements or suggest other processes have not been accounted for in the regression model. The residuals to the final fit maintain a Gaussian behavior around a mean DIC value of 0 (Figure 2), which is the first test that the linear assumption holds for our model. The spatial distribution of the residuals also show no clear pattern related to either water masses or processes that have not been accounted for (Figure 2). One of the criteria used to determine our empirical fit for DIC was that concurrent CFC measurement was available so as to normalize all measurements to the year 1995. As an added test we compare these independent DIC measurements to those predicted using our empirical fit and find no evidence for spatial patterns or biases (Figure 3).

[16] Surface alkalinity has been shown to closely follow the salinity distribution in the Southern Ocean [Jabaud-Jan et al., 2004; Metzl et al., 1999; Millero et al., 1998]. We explored empirical predictions of surface ALK using four times the number of surface measurements $(\sim 1200)$ previously available to Millero et al. [1998]. We found the inclusion of salinity, nitrate and silicate improved the empirical estimations to within $8.1 \mu \mathrm{mol} / \mathrm{kg}$ (Figure 2), described by the equation; $A L K=678.5+46.6 \times S+0.8 \times$ $\mathrm{Nit}+0.3 \times \mathrm{Sil}, \mathrm{R}^{2}=0.74$. As opposed to DIC however, there is some indication of spatial patterns to the residuals, particularly in the low latitudes (Figure 2). Alkalinity variations are controlled by mixing, dilution and $\mathrm{CaCO}_{3}$ production/dissolution, although $\mathrm{CaCO}_{3}$ production is small in the Southern Ocean on the basis of surface budgets [Sarmiento et al., 2002] and from sediment trap data [Trull et al., 2001]. Salinity is independent to $\mathrm{CaCO}_{3}$ production and introducing temperature to our empirical fit made no difference to its predictive capabilities.

[17] A recent study found similar uncertainty to our empirical fit for ALK, using salinity and temperature [Lee et al., 2006]. Although those relationships are undisputed from a spatial extent, we found temporal biases when using temperature as a variable in our empirical model. The inclusion of temperature induced an erroneously large seasonal cycle of ALK, particularly in the SAZ, which is not seem in previous observations or those used here (Figure 3). Owing to this fact, we excluded temperature from our empirical estimation which resulted in no worse uncertainty for our fits. More ALK observations in the Southern Ocean will be extremely valuable in reducing our predictive uncertainties.

\subsection{Extrapolation of DIC and ALK}

[18] The 2001 World Ocean Atlas includes over 52000 surface measurements in the Southern ocean that were used to develop a seasonal climatology for temperature, salinity, oxygen and nutrients. This climatology is used in conjunction with the empirical fits for DIC/ALK to estimate the 

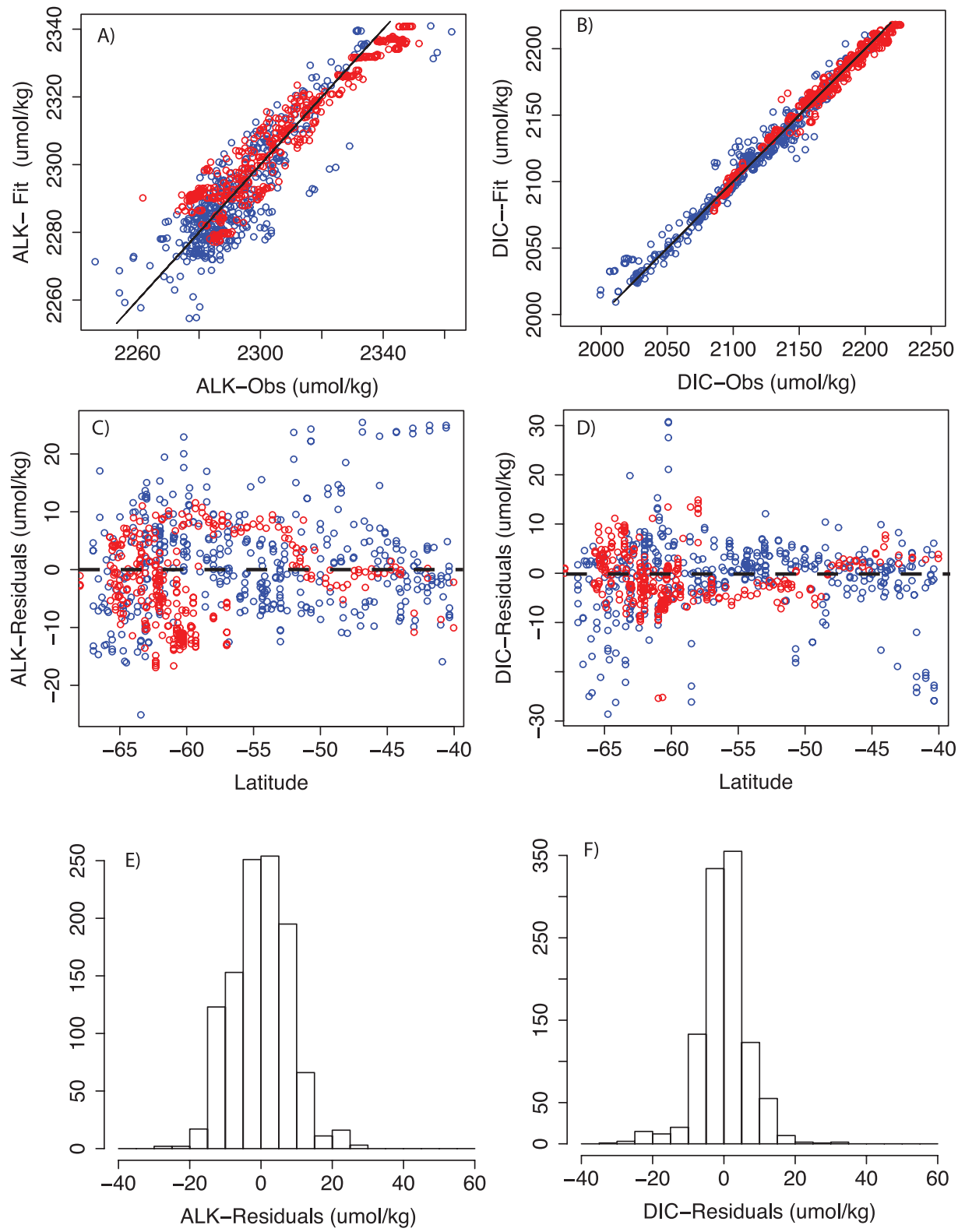

Figure 2. (a) MLR for surface Alkalinity using temperature and salinity as predictors: $A L K=678.5+$ $46.6 \times S+0.8 \times N i t+0.3 \times S i l, \mathrm{SE}=8.1 \mu \mathrm{mol} / \mathrm{kg}$, and (b) MLR for surface DIC measurements using temperature, salinity, oxygen, nitrate, phosphate and silicate as predictors, $D I C=883.9-6.6 \times \theta+37.7 \times$ $\mathrm{Sal}-0.3 \times \mathrm{O}_{2}+2.9 \times \mathrm{Nit}+0.3 \times \mathrm{Sil} ; \mathrm{SE}=8.5 \mu \mathrm{mol} / \mathrm{kg}$. Blue denotes summer measurements while red denote winter measurements. (c, d) Spatial pattern of the residuals to the empirical fit. (e, f) Histograms of the residuals for DIC and ALK fits.

seasonal distribution of both DIC and ALK in the Southern Ocean. If the climatological data set reproduces the observed seasonal variability of temperature, salinity, oxygen and nutrients exactly then DIC should be predicted to within $\sim 8 \mu \mathrm{mol} / \mathrm{kg}$ while ALK to within $\sim 10 \mu \mathrm{mol} / \mathrm{kg}$. However, systematic (temporal and spatial) biases in the WOA01 climatology as well as our carbon data are inevitable. We use 5 parameters in estimating DIC empirically and any systematic bias due to the lack of data coverage in the WOA01 climatology will express itself directly in the DIC extrapolation. To explore these possible biases we compare the observed zonal average seasonal DIC concentrations to those predicted empirically via our empirical extrapolation. The structure, magnitude and seasonal drawdown in our extrapolated DIC compares relatively closely to the observations (Figure 3) with some slight deviations during winter. 

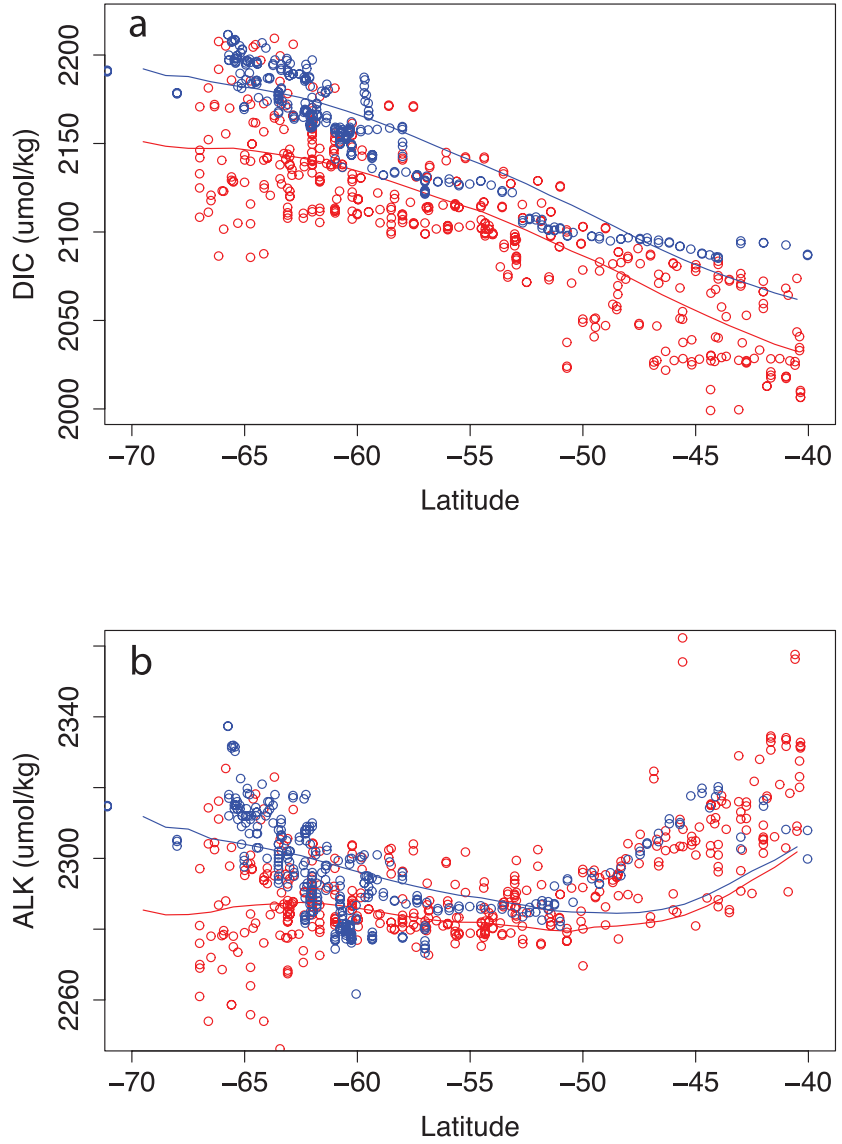

Figure 3. All (a) DIC and (b) ALK measurements ( $\mu \mathrm{mol} /$ $\mathrm{kg}$ ) for summer (red) and winter (blue). The zonally averaged predictions from our methodology are shown by the solid colored lines.

The good comparison implies that the possible systematic biases introduced in using the WOA01 temperature, salinity, oxygen and nutrient climatology is relatively small and gives us confidence in our predictive extrapolations for DIC on the larger scale.

\subsection{The $\mathrm{pCO}_{2}$ Calculations and Optimal Dissociation Constants}

[19] Oceanic measurements of inorganic carbon include four species: dissolved inorganic carbon (DIC), alkalinity (ALK), partial pressure of $\mathrm{CO}_{2}\left(\mathrm{pCO}_{2}\right)$ and $\mathrm{pH}$. Any two of these species may be used to determine the concentration of the other species via carbonate chemistry equilibria calculations. Dissociation constants for $\mathrm{CO}_{2}$ chemistry are a prerequisite to calculate other inorganic carbon species. Many different constants have been proposed. The most direct way of investigating the optimal set of constants is through the analysis of discrete carbon measurements of DIC, ALK and $\mathrm{pCO}_{2}$ that have been gathered on a single sample. In this way $\mathrm{pCO}_{2}$ can be calculated from DIC and ALK and then compared with the $\mathrm{pCO}_{2}$ measurements to investigate different sets of dissociation constants. Using this method [Lee et al., 2000a] analyzed dissociation constants proposed by Roy et al. [1993] and Mehrbach et al. [1973] as refit by Dickson and Millero [1987] (hereinafter referred to as DM87) on 5 sets of oceanic carbon measurements and recommended the use of those proposed by DM87. Here we compliment these other studies by analyzing over 1500 surface measurements in the Southern Indian Ocean to identify the optimal $\mathrm{CO}_{2}$ dissociation constants for our study.

[20] Two cruises were conducted during year 2000 in the south-western Indian Ocean onboard the R.S.S. MarionDufresne (IPEV/TAAF) as part of the OISO program (Océan Indien Service d'Observations, INSU/IPSL): one during austral summer (January 2000), one in winter (August 2000). Over 1500 continuous sea surface samples were measured for temperature (SST), salinity (SSS), fluorescence, $\mathrm{CO}_{2}$ fugacity $\left(\mathrm{fCO}_{2}\right)$, total dissolved inorganic carbon (DIC) and total alkalinity (TA). These data are discussed by Metzl et al. [2006].

[21] To determine the optimal dissociation constants we calculated $\mathrm{fCO}_{2}$ using the measured SST, SSS, DIC and ALK and compared those to the measured $\mathrm{fCO}_{2}$. Climatologically derived surface phosphate and silicate concentrations were also used in the calculations, which were found to be important for alkalinity due to high concentrations in the Southern Ocean. Four sets of dissociation constants were tested [Dickson and Millero, 1987; Goyet and Poisson, 1989; Hansson, 1973; Roy et al., 1993]. The analysis confirmed the optimal dissociation constants to be those proposed by DM87 which adds considerable weight to the conclusions of previous studies [Lee et al., 2000a; Millero et al., 2002] considering the large number of samples $(\mathrm{n}=1563)$ used. The main benefit of our results however, is that we can directly attribute an uncertainty $(3.6 \pm 3 \mu \mathrm{atm}$ : see Figure 4) to our $\mathrm{pCO}_{2}$ calculations that can then be used explicitly within our Monte Carlo uncertainty analysis of the Southern Ocean net air-sea $\mathrm{CO}_{2}$ flux.

[22] In calculating the $\mathrm{pCO}_{2}$ distribution (Figure 5) using DM87 dissociation constants we included the seasonal phosphate/silicate concentrations within the definition of alkalinity, which was found to be important. We calculate the $\mathrm{pCO}_{2}$ in the surface ocean for each $1^{\circ} \times 1^{\circ}$ grid box over each season, where austral winter is taken to be between months between June to August, spring (September to November), summer (December to February) and autumn (March to May).

\subsection{Flux Calculation}

[23] The air-sea $\mathrm{CO}_{2}$ flux is determined via $F=$ $k \alpha\left(\Delta p \mathrm{CO}_{2}\right)$, where $\mathrm{k}=$ gas transfer coefficient, $\alpha=$ solubility of $\mathrm{CO}_{2}$ in seawater, and $\Delta \mathrm{pCO}_{2}=$ the difference between oceanic $\mathrm{pCO}_{2}$ and atmospheric $\mathrm{pCO}_{2}$. Atmospheric $\mathrm{pCO}_{2}$ is computed using the $\mathrm{CO}_{2}$ concentration in dry air for the year 1995 from the GLOBALVIEW database [GLOBALVIEW-CO2, 2003]. A correction was applied to convert the dry air concentrations to wet air concentrations in the same manner as that of T02 in order to equate the aqueous $\mathrm{pCO}_{2}$ concentration in the ocean to that of the atmosphere. Furthermore, variations in atmospheric pressure were also taken into account by using the climatological monthly mean barometric pressure. We use daily 


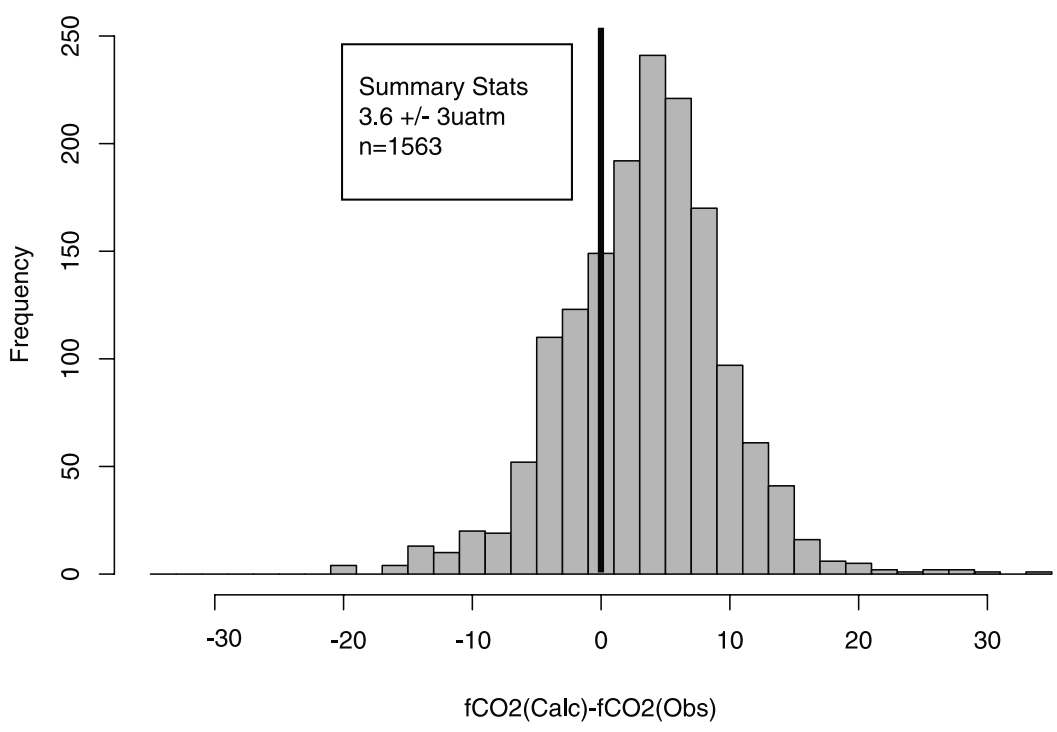

Figure 4. Histogram of $\mathrm{fCO}_{2}$ (calculated) - $\mathrm{fCO}_{2}$ (observed) for both summer and winter cruises using the $\mathrm{CO}_{2}$ dissociation constants from Mehrbach et al. [1973] as refit by Dickson and Millero [1987]. The number of samples were 1563 with the difference being $3.6 \pm 3 \mu \mathrm{atm}$ using the optimal dissociation constants.

NCEP 41-year mean $10 \mathrm{~m}$ wind speeds averaged for each season along with the [Wanninkhof, 1992] gas transfer velocity relationship for our air-sea flux estimates. We quantify sea-ice impacts on the $\mathrm{CO}_{2}$ flux in the Southern Ocean using the monthly averaged sea-ice concentrations for the Southern Hemisphere derived from the Nimbus-7 Scanning Microwave Radiometer (SMMR) and the Defense Meteorological Satellite Programs DMSP-F8, F-11 and F-13 and a bootstrap algorithm. The $\mathrm{CO}_{2}$ flux was assumed proportional to the percent ice-free area within each $1^{\circ} \times$ $1^{\circ}$ grid box. This differs from T02 who set the flux to 0 for regions with ice coverage greater than $50 \%$.

\section{Results and Discussion}

\subsection{General Southern Ocean Carbon Dynamics: Links to Ocean Ventilation}

[24] The Southern Ocean is broadly characterized by three different oceanic regimes separated by fronts defined by strong meridional property gradients. From south to north the fronts are: the Polar Front (PF), the sub-Antarctic Front (SAF) and the subtropical Front (STF) [Orsi et al., 1995] (Figure 5). The oceanic regions bounded by these fronts (and Antarctica) include: the Antarctic Zone (AZ), the Polar Frontal Zone (PFZ) and the sub-Antarctic zone (SAZ). Surface inorganic carbon concentrations are largely determined by large-scale mixing processes within each region.

[25] Figure 5 shows the estimated surface DIC, ALK and $\mathrm{pCO}_{2}$ concentrations for winter and summer. The Southern Ocean is usually regarded as longitudinally homogenous area dominated by the circumpolar ACC transport. For carbon dynamics, our results suggests strong regional differences in both seasonality and spatial structure particularly in the AZ. Higher DIC concentrations during the winter (associated with enhance vertical mixing) are observed with summer drawdown of DIC (associated with biological production). Although there is considerable spatial variability in our empirical extrapolations, we find the Polar Front (Figure 5) to be a distinctive marker between DIC rich water to the south and more carbon-depleted water to the north. Surface ALK shows a smaller seasonal change $(0-20 \mu \mathrm{mol} / \mathrm{kg})$ than DIC $(0-60 \mu \mathrm{mol} / \mathrm{kg})$ most likely due to the predominance of organic carbon export over inorganic carbon export in the Southern Ocean [Sarmiento et al., 2002]. Zonally averaged DIC concentrations for winter increase from about 2060 to $2200 \mu \mathrm{mol} / \mathrm{kg}$ between $40^{\circ} \mathrm{S}$ and $70^{\circ} \mathrm{S}$, with a summertime depletion of between 30 and $50 \mu \mathrm{mol} / \mathrm{kg}$ and are consistent in structure and magnitude to the available DIC measurements (Figure 6).

[26] There are clear links between the seasonal carbon dynamics and known areas of deep water ventilation and Antarctic bottom water formation regions. In the Weddell Sea and southeast Pacific, the seasonal winter to summer change $(<80 \mu \mathrm{mol} / \mathrm{kg})$ appears higher than in the South Indian (Figure 6). This is consistent with the few seasonal observations in the Pacific [Rubin, 2003] and Indian Ocean [Metzl et al., 2006]. The $\mathrm{pCO}_{2}$ change from winter to summer shows particularly interesting structure in the AZ, coinciding with the carbon rich waters estimated from our DIC/ALK extrapolations. Localized intense high $\mathrm{pCO}_{2}$ events $(\sim 420 \mu \mathrm{atm})$ are estimated during the winter in the Weddell Sea and also along the Adelie-land coastline, both of which are know bottom water regions [Rintoul, 1998].

[27] Regional biases within the WOA01 database translate directly into our $\mathrm{pCO}_{2}$ estimates. It would therefore be unwise to use our estimates to investigate small-scale regional variations in either $\mathrm{pCO}_{2}$ or the air-sea $\mathrm{CO}_{2}$ flux. Although it would be premature to definitively conclude that strong wintertime deep-water ventilation is linked to intense $\mathrm{CO}_{2}$ outgassing, these areas coincide well with our 

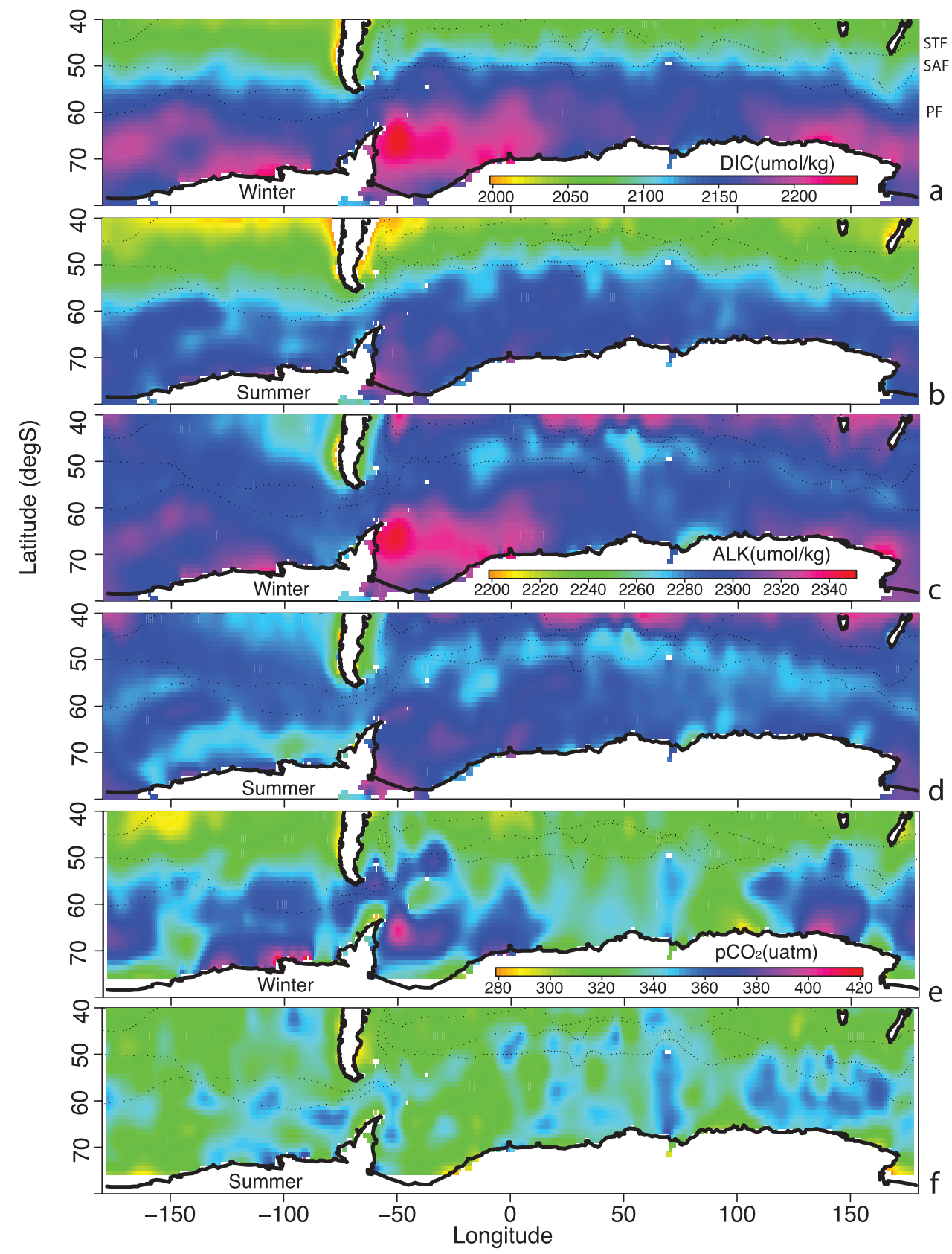

Figure 5. (a) Winter surface DIC concentrations $(\mu \mathrm{mol} / \mathrm{kg})$ as extrapolated using our methodology, (b) summer DIC concentrations, (c) winter ALK concentrations, (d) summer ALK concentrations, (e) winter $\mathrm{pCO}_{2}$ estimate, and (f) summer $\mathrm{pCO}_{2}$ estimate. The STF is the subtropical front, SAF the subAntarctic Font and PF the Polar Front. These front definitions are from Orsi et al. [1995].

understanding of the physical oceanographic processes within the Southern Ocean. During autumn/winter, cooling induces deeper convection which 'ventilates' old circumpolar deep water (CDW). These deep waters are rich in inorganic carbon and nutrients due to accumulation of remineralized organic matter. The $\mathrm{CO}_{2}$ source south of $60^{\circ} \mathrm{S}$ during autumn/winter from our results is most likely due to this CDW ventilation and associated outgassing. Wintertime outgassing due to ocean ventilation was not evident in previous large-scale analyses and deserves further investigation particularly considering the potential impact of enhanced stratification in these areas due to climate change.

[28] During summer (Figure 5) the region south of the PF shows a sustained lowering of $\mathrm{pCO}_{2}$ relative to the atmosphere. Stable mixed layers and sea-ice dynamics promote considerable biological production in the Antarctic Zone [Gibson and Trull, 1999; Nicol et al., 2000; Sweeney, 2003] as is also identified by an $80 \mu \mathrm{mol} / \mathrm{kg}$ drawdown in surface DIC in certain regions (Figure 6). The spring/summer drawdown in $\mathrm{pCO}_{2}$ in the $\mathrm{AZ}$ more than offsets the source 


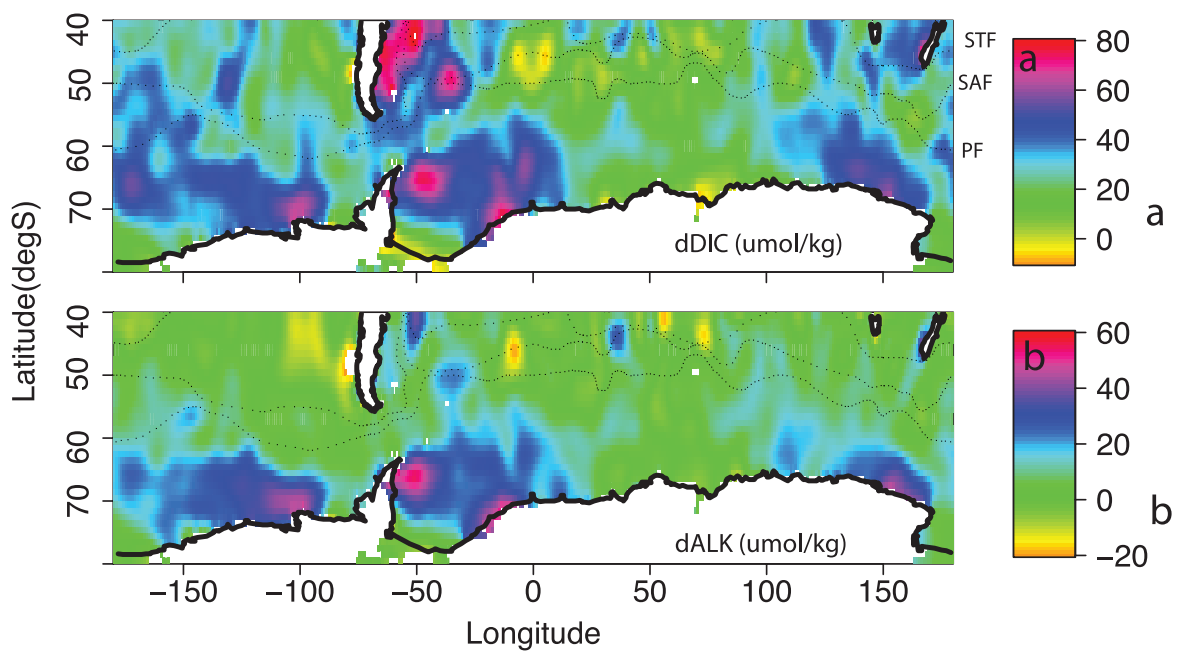

Figure 6. (a) Change in surface DIC concentrations ( $\mu \mathrm{mol} / \mathrm{kg})$ from winter to summer and (b) change in surface ALK concentrations from winter to summer (i.e., winter-summer).

during autumn/winter as the annual average $\Delta \mathrm{pCO}_{2}$ is in quasi-equilibrium ( -10 to $0 \mu \mathrm{atm})$ with the atmosphere for the AZ (see Figure 7).

[29] The Polar Frontal Zone (PFZ) is at the core of the eastward flowing Antarctic Circumpolar Current (ACC) and is characterized by strong lateral mixing and relatively low biological production [Rintoul and Trull, 2001] as indicated by a relatively low seasonal DIC depletion $(\sim 20 \mu \mathrm{mol} / \mathrm{kg})$ in comparison to other zones (Figure 6). However, sediment trap data suggests relatively high organic carbon fluxes [Trull et al., 2001] south of Australia. High mixing may possibly be masking the DIC depletion attributed to biological production. Our annually averaged PFZ results maintain a surface $\mathrm{pCO}_{2} \sim 10 \mu \mathrm{atm}$ lower than the atmosphere indicating a weak sink (see Figure 7).

[30] The transition from the PFZ to the Sub-Antarctic Zone (SAZ) is quite distinct (Figure 5) with the SAZ maintaining a $\mathrm{pCO}_{2}$ that is $\sim 30 \mu \mathrm{atm}$ lower than the atmosphere. The SAZ is characterized by deep convective mixed layers $(>500 \mathrm{~m})$ during winter and relatively stable shallow mixed layers during summer [Rintoul and Trull, 2001]. These deep mixed layers formed during winter are subducted northward below poleward moving subtropical waters (Figure 7). This relatively stable pycnostad is known as sub-Antarctic Mode Water (SAMW) and extends up to the subtropical gyres, while Antarctic Intermediate Water (AAIW) is also thought to form in the southeastern Pacific SAZ via anomalously cooler and fresher convection [McCartney, 1977]. This strong convective mixing in the winter usually resets oceanic $\mathrm{pCO}_{2}$ to be in equilibrium with the atmosphere [Metzl et al., 1999]. Our estimates show that the SAZ maintains a strong sink all year, not consistent with direct $\mathrm{pCO}_{2}$ observations and an attempt will be made later in the paper on why this is the case.

\subsection{What is Driving the Seasonal Variations in $\mathrm{pCO}_{2}$ ?}

[31] The major properties which influence the seasonal $\mathrm{pCO}_{2}$ change are known from our methodology (SST,
Salinity, DIC and ALK). We can therefore perform a simple decomposition in order to understand which properties are most critical. The change in $\mathrm{pCO}_{2}$ between winter and summer $\left(\triangle \mathrm{pCO}_{2}\right)$ can be written as

$$
\begin{aligned}
\Delta p \mathrm{CO}_{2}= & \frac{\partial p C \mathrm{O}_{2}}{\partial S S T} \Delta S S T+\frac{\partial p C \mathrm{O}_{2}}{\partial \mathrm{Sal}} \Delta \mathrm{Sal} \\
& +\frac{\partial p C \mathrm{O}_{2}}{\partial A L K} \Delta A L K+\frac{\partial p C \mathrm{O}_{2}}{\partial D I C} \Delta D I C .
\end{aligned}
$$

Each component in this equation was calculated by holding the other three components constant, so as to determine the relative influence of each property on the winter to summer change in $\mathrm{pCO}_{2}$.

[32] Figure 8a shows the winter to summer $\mathrm{pCO}_{2}$ distribution. Within the AZ, winter values are up to $40 \mu \mathrm{atm}$ higher than summer, consistent with previous observations and physical oceanographic understanding of wintertime ventilation bringing high $\mathrm{pCO}_{2}$ to the surface. However, as previously noted, our estimates suggest the wintertime $\mathrm{pCO}_{2}$ levels are up to $20 \mu \mathrm{atm}$ lower than summer values particularly in the South Pacific and central Indian. Lower wintertime values of $\mathrm{pCO}_{2}$ have not been observed and are inconsistent with deep wintertime convective mixing which would elevate $\mathrm{pCO}_{2}$ in the $\mathrm{SAZ}$ during the winter. The decomposition is particularly useful in trying to explain why our estimates suggest very low wintertime values of $\mathrm{pCO}_{2}$ in the SAZ. Figures $8 b-8 d$ shows the relative contribution of each property in driving the winter-summer $\mathrm{pCO}_{2}$ difference. Salinity is not shown because it had a negligible influence in comparison to the other three components. Figure 9 shows a zonal plot of the contributions of each parameter to the winter-summer $\mathrm{pCO}_{2}$ difference.

[33] Seasonal changes in temperature impact the $\mathrm{pCO}_{2}$ considerably owing to solubility effects. Seasonal cycle of temperature is more pronounced moving north into the $\mathrm{SAZ}$, while seasonal temperature changes are small in the $\mathrm{AZ}$ (Figure 8b). Strong winter cooling lowers $\mathrm{pCO}_{2}$ in the 


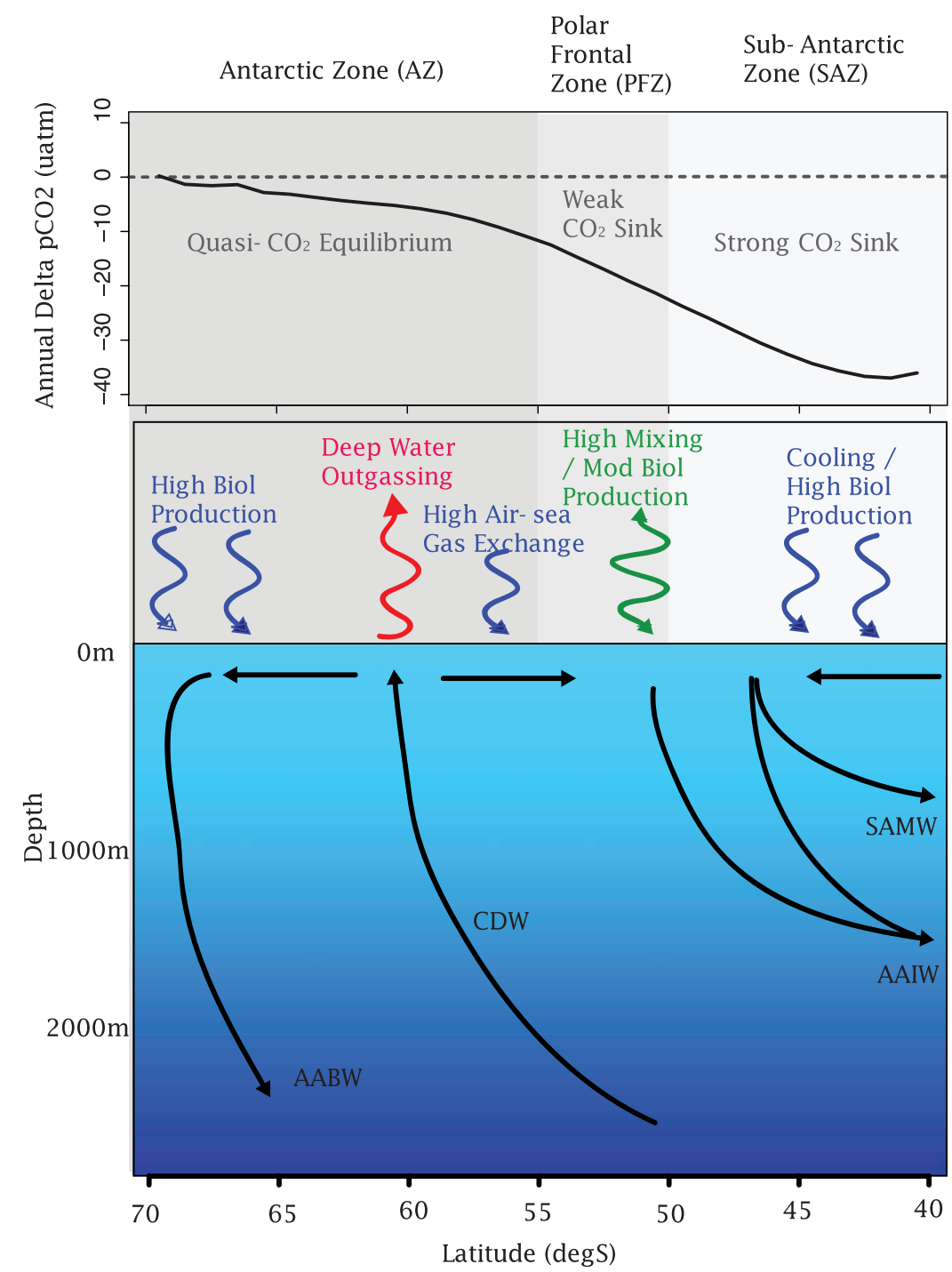

Figure 7. Zonally averaged annual delta $\mathrm{pCO}_{2}$ distribution (sea-air) based on our results in relation to Southern Ocean zoning (Sub-Antarctic Zone, Polar Frontal Zone, and Antarctic Zone) and circulation pathways (AABW, Antarctic Bottom Water; CDW, Circumpolar Deep Water; AAIW, Antarctic Intermediate Water; SAMW, Sub-Antarctic Mode Water).

SAZ, by up to $70 \mu$ atm in winter, with the largest influence in the Pacific sector of the SAZ. Farther south, the temperature influence decreases to be less than $20 \mu \mathrm{atm}$.

[34] Winter to summer drawdown in DIC will also have an important impact on the seasonal $\mathrm{pCO}_{2}$ changes. As shown previously, seasonal changes of up to $80 \mu \mathrm{mol} / \mathrm{kg}$ are found in the South Atlantic (Figure 6) and as expected is the strongest influence on the winter to summer change is $\mathrm{pCO}_{2}$ (Figure 8c). Winter increases in DIC due to enhanced vertical mixing in comparison to the low values during summer due to biological productivity increase $\mathrm{pCO}_{2}$ everywhere in the Southern Ocean up to $+150 \mu \mathrm{atm}$. The AZ shows the largest influence due to DIC with other regions like the SAZ showing far less DIC influence on driving the seasonal $\mathrm{pCO}_{2}$ changes $(<+50 \mu \mathrm{atm})$. These strong DIC increases more than offset the lower $\mathrm{pCO}_{2}$ due to cooling, particularly in the AZ (Figure 9). However, in the SAZ, the DIC effects are not large enough to offset the strong temperature induced signal on the seasonal $\mathrm{pCO}_{2}$ cycle.

[35] Alkalinity, as expected has a larger influence on the $\mathrm{pCO}_{2}$ cycle farther south in the $\mathrm{AZ}$, where inorganic biological production is known to occur, as opposed to the SAZ. In the AZ, we find that there would much larger winter outgassing of $\mathrm{CO}_{2}$ if not for the significant drawdown $(<60 \mu \mathrm{atm})$ relating to ALK changes on the $\mathrm{pCO}_{2}$ cycle.

[36] Lateral mixing within the SAZ will also have an important influence on the $\mathrm{pCO}_{2}$ cycle which the current decomposition cannot elucidate. The degree to which subtropical waters influence the sub-Antarctic zone is important for $\mathrm{CO}_{2}$ uptake as they cool and lower their $\mathrm{pCO}_{2}$ while moving southward into the SAZ. Extensive biological 


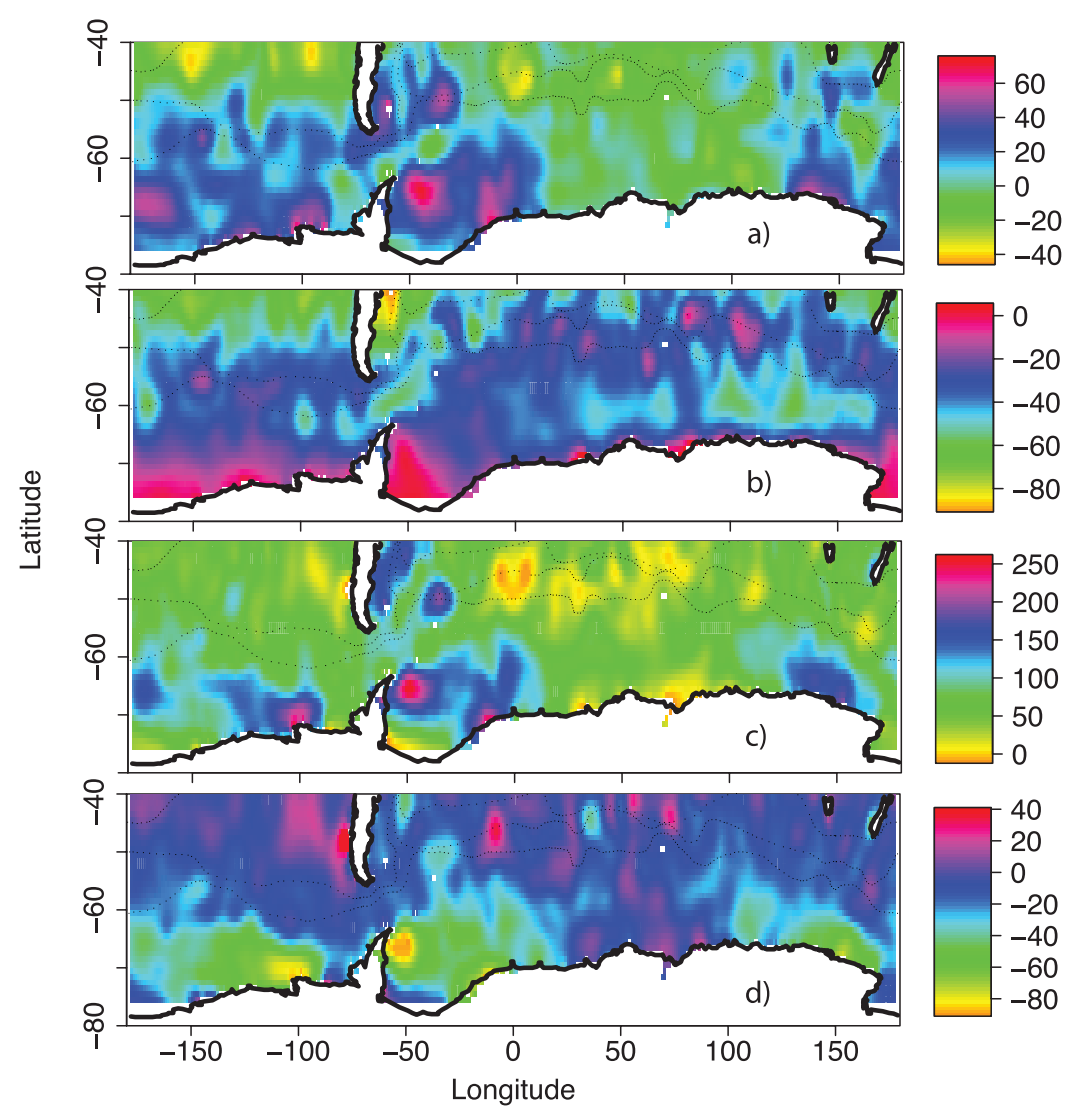

Figure 8. (a) Seasonal difference between winter and summer $\mathrm{pCO}_{2}$ ( $\left.\mu \mathrm{atm}\right)$ calculated from our empirical methodology. Red indicate regions where winter $\mathrm{pCO}_{2}$ is higher than summer, while light blue/ green indicate regions where winter $\mathrm{pCO}_{2}$ is lower than summer. (b) Winter to summer changes in $\mathrm{pCO}_{2}$ due to sea surface temperature. (c) Winter to summer changes in $\mathrm{pCO}_{2}$ due to DIC. (d) Winter to summer changes in $\mathrm{pCO}_{2}$ due to $\mathrm{ALK}$ (see equation (2) in text for clarification).

production occurs in the SAZ during spring/summer, as shown via nutrient analysis [Lourey and Trull, 2001] and sediment trap data [Trull et al., 2001]. The extent to which the SAZ acts as a $\mathrm{CO}_{2}$ sink is also dependent on the strength of meridional Ekman transport across the PFZ. This transport has been found to have a significant influence on interannual air-sea flux variability [Rintoul and England,
2002]. A predominance of Ekman fluxes across the PFZ would elevate the $\mathrm{pCO}_{2}$ in the $\mathrm{SAZ}$ and this is not consistent with our annually averaged estimates.

[37] Our decomposition analysis illustrates a number of important considerations in understanding the seasonal $\mathrm{CO}_{2}$ cycle. First, upwelled deep waters in the AZ bring high DIC and ALK concentrations into the surface layer.

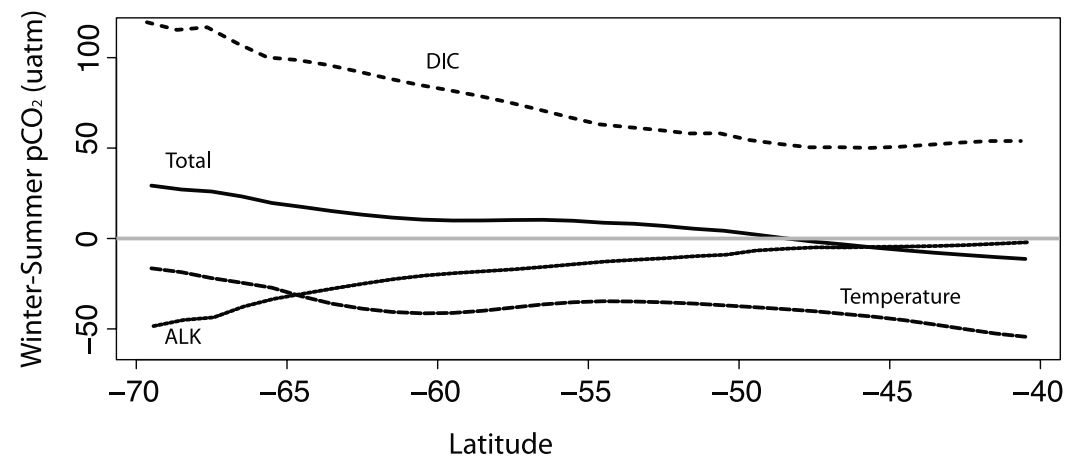

Figure 9. Zonally averaged changes in $\mathrm{pCO}_{2}$ from winter to summer. The contribution of each property (DIC, ALK, and SST) to the seasonal changes in $\mathrm{pCO}_{2}$ is calculated via equation (2) in the text. 


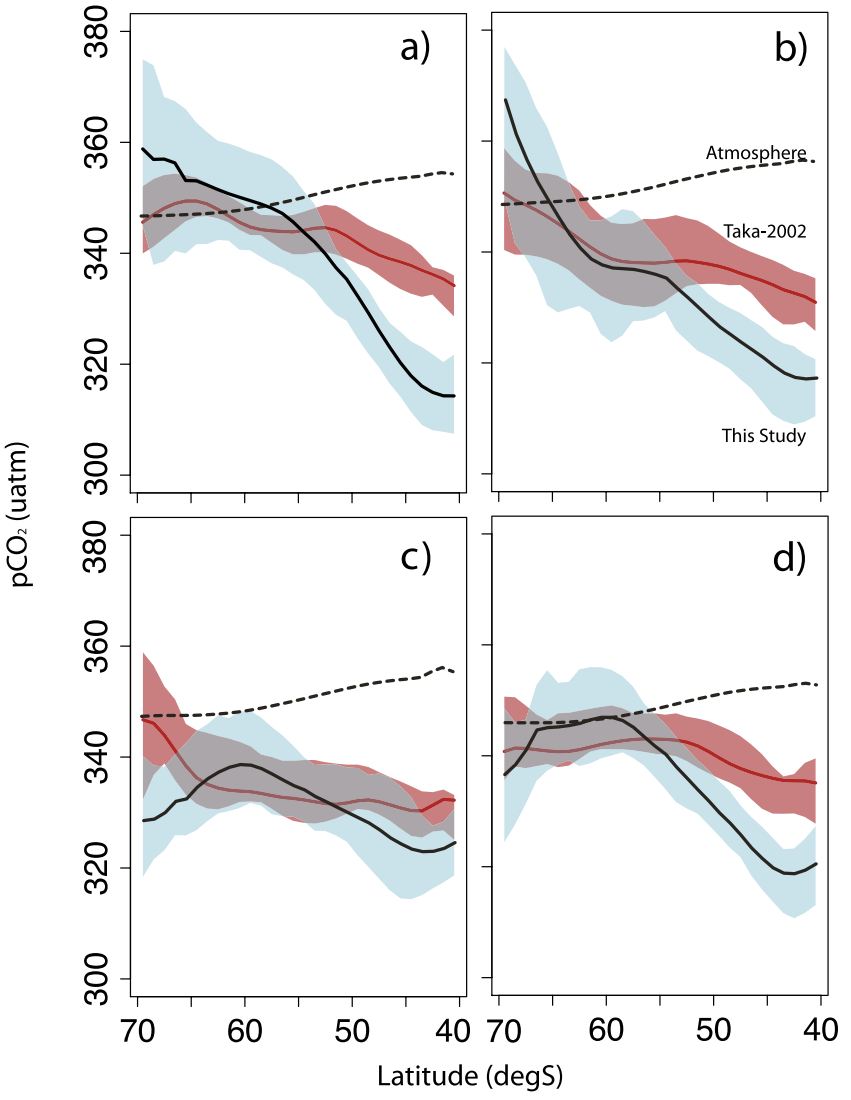

Figure 10. Zonal average $\mathrm{pCO}_{2}(\mu \mathrm{atm})$ distribution for each season in the Southern Ocean. (a) Winter (June to August). (b) Spring (September to November). (c) Summer (December to February). (d) Autumn (March to May). The solid black line shows our mean estimates and blue shading is the combined random uncertainty and zonal variability. The dashed line represents atmospheric $\mathrm{pCO}_{2}$ in 1995. The red line shows the zonal mean T02 estimates. For T02, there is no estimate of uncertainty and the red shading only represents average zonal variability.

This DIC creates a strong spike in $\mathrm{pCO}_{2}$ in the surface water $(>+100 \mu \mathrm{atm})$, but this is mediated by the coinciding $\mathrm{pCO}_{2}$ drawdown in winter associated with high $\operatorname{ALK}(>-50 \mu \mathrm{atm})$. The AZ wintertime outgassing is therefore half the magnitude due to the importance of the ALK cycle (which is dominated by inorganic biological production and vertical mixing). Secondly, the anomalously low $\mathrm{pCO}_{2}$ values in the wintertime SAZ arise owing to extensive cooling which overcompensates the comparatively weaker enrichment of DIC due to vertical mixing. The ALK cycle plays little role in the SAZ as opposed to the AZ (Figure 9).

\subsection{Comparison With Other Independent Estimates}

[38] The $\mathrm{T} 02 \mathrm{pCO}_{2}$ climatology is based on the largest accumulation of high-quality surface $\mathrm{pCO}_{2}$ measurements and warrants a careful comparison to our empirically derived estimates. Our summertime $\mathrm{pCO}_{2}$ estimates agree with T02 (Figure 10). This is encouraging given that summer is well sampled in the T02 database consequently unlikely to have large bias. Furthermore, taking into account the uncertainties, our estimates are generally in agreement with $\mathrm{T} 02$ in the $\mathrm{AZ}$ (south of $55^{\circ} \mathrm{S}$ ). The main differences between the two estimates are found between autumn and spring in the SAZ where our estimates are $\sim 10$ to $20 \mu \mathrm{atm}$ lower than T02. As discussed earlier the temperature component outweighs the DIC component in driving SAZ $\mathrm{pCO}_{2}$ changes with our methodology. Further analysis with $\mathrm{pCO}_{2}$ observations is needed to resolve this discrepancy. Despite this, both methods suggest a moderate to large $\mathrm{CO}_{2}$ sink in the SAZ with the mechanisms driving this discussed earlier (Figure 11).

[39] Figure 12 shows our annual estimate for the $\mathrm{CO}_{2}$ seaair flux for 1995 with negative values implying oceanic $\mathrm{CO}_{2}$ uptake. Table 2 compares our integrated air-sea $\mathrm{CO}_{2}$ flux estimate with other independent methodologies. The most common oceanographic definition of the Southern Ocean is the region south of the subtropical front, which is generally centered around $40^{\circ} \mathrm{S}$ latitude (Figure 5). Although the meridional definition varies considerably, most previous

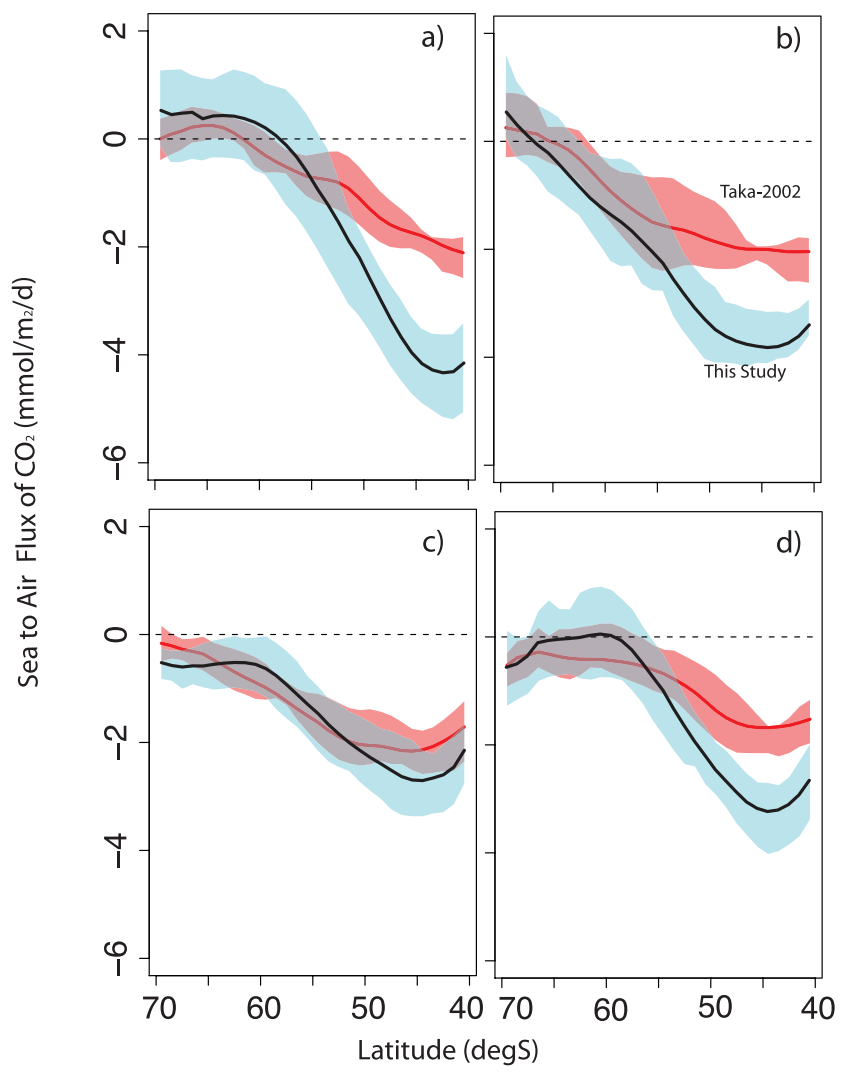

Figure 11. Zonally averaged sea-air $\mathrm{CO}_{2}$ flux for each season in the Southern Ocean. (a) Winter (June to August). (b) Spring (September to November). (c) Summer (December to February). (d) Autumn (March to May). The solid black line shows our mean estimates and blue shading is the associated random uncertainty and combined zonal variability. The red line shows the zonally averaged T02 flux estimates. For T02, there is no estimate of uncertainty and the red shading only represents average zonal variability. Negative values imply flux into the ocean. 


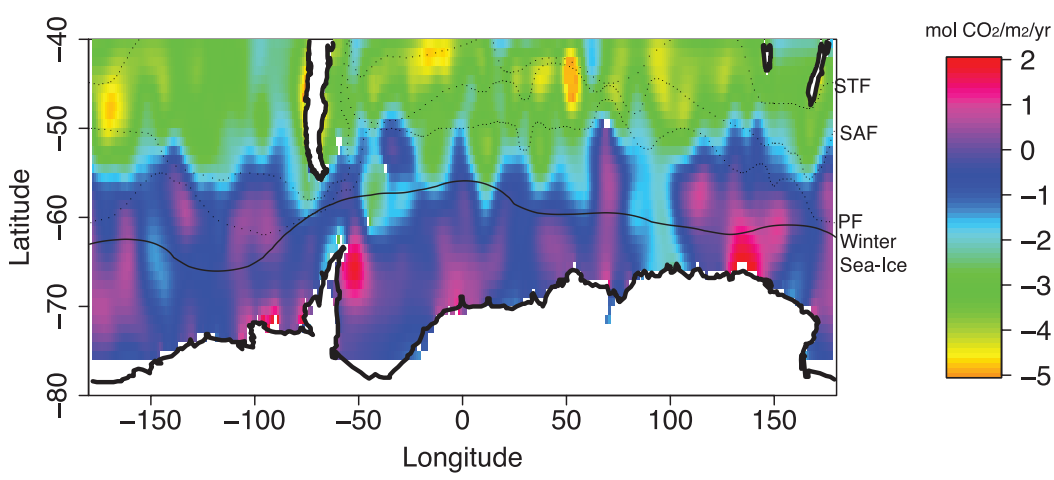

Figure 12. Annual net sea-air $\mathrm{CO}_{2}$ flux $\left(\mathrm{mol} \mathrm{CO} / \mathrm{m}_{2} / \mathrm{yr}\right)$ including the effects of sea ice. Negative values imply flux into the ocean. Sea-ice extent is shown for winter and taken to be the $10 \%$ concentration isopleth. A negative flux implies the ocean to be a sink. Dotted lines show Southern Ocean Fronts; STF (Subtropical Front); SAF (Sub-Antarctic Front) and PF (Polar Front).

flux estimates have taken the Southern Ocean to be south of $50^{\circ} \mathrm{S}$ (Table 2). The results show differing magnitudes in the meridional uptake of $\mathrm{CO}_{2}$ in the Southern Ocean depending on the method used. For the region south of $50^{\circ} \mathrm{S}$, we estimate an oceanic sink of $0.4 \pm 0.25 \mathrm{Pg} \mathrm{C} / \mathrm{yr}$, which is in reasonable agreement with ocean-based methods such as T02corr ( $\sim 0.35 \mathrm{Pg} \mathrm{C} / \mathrm{yr})$ and within uncertainties of Louanchi and Hoppema [2000] (0.5 to $0.8 \mathrm{Pg} \mathrm{C/yr)} \mathrm{who}$ use a semiprognostic model constrained to observations such as chl-a, temperature, salinity and mixed layer depth. New oceanic $\mathrm{pCO}_{2}$ measurements within the Indian sector of the Southern Ocean point to a weak sink south of $50^{\circ} \mathrm{S}$ [Metzl et al., 2006]. Metzl et al. [2006] used seasonal $\mathrm{pCO}_{2}$ measurements from 2000 and extrapolate using the 1-D biogeochemical model of Louanchi et al. [1996]. They found a considerably weaker $\mathrm{CO}_{2}$ sink south of the Polar Front $(\sim 0.17 \mathrm{Pg} \mathrm{C} / \mathrm{yr})$ but within the uncertainty our result $(\sim 0.4 \pm 0.25 \mathrm{Pg} \mathrm{C} / \mathrm{yr})$. They suggested the weaker sink is due to the inclusion of winter $\mathrm{pCO}_{2}$ measurements. The results from Metzl et al. [2006] and our study suggest the possibility of winter outgassing south of the PF. South of $50^{\circ} \mathrm{S}$ our results are within the uncertainties of atmospheric inversion estimates [Gurney et al., 2002; Patra et al., 2005].

[40] For the sub-Antarctic Zone $\left(\mathrm{SAZ} \sim 40^{\circ} \mathrm{S}-50^{\circ} \mathrm{S}\right)$, we estimate a $\mathrm{CO}_{2}$ sink of $\sim 1.1 \mathrm{Pg} \mathrm{C} / \mathrm{yr}$ which is large thereby dominating the Southern Ocean air-sea $\mathrm{CO}_{2}$ flux. Metzl et al. [1999] estimated the annual cycle of $\mathrm{pCO}_{2}$ in the $\mathrm{SAZ}$ by extrapolating measurements taken within the Indian Ocean to the circumpolar sub-Antarctic Ocean. They estimate an annual $\mathrm{CO}_{2}$ sink between 1992 and 1995 and $1 \mathrm{Pg} \mathrm{C} / \mathrm{yr}$

Table 2. Recent Estimates of the Contemporary $\mathrm{CO}_{2}$ Flux in the Southern Ocean

\begin{tabular}{|c|c|c|c|c|c|c|c|}
\hline \multirow[b]{2}{*}{ Methodology } & \multirow[b]{2}{*}{ Reference } & \multicolumn{6}{|c|}{ Net Sea-Air $\mathrm{CO}_{2}$ Flux, $\mathrm{Pg} \mathrm{C} / \mathrm{yr}$} \\
\hline & & $40^{\circ} \mathrm{S}-50^{\circ} \mathrm{S}$ & $50^{\circ} \mathrm{S}-60^{\circ} \mathrm{S}$ & $60^{\circ} \mathrm{S}-70^{\circ} \mathrm{S}$ & $40^{\circ} \mathrm{S}-60^{\circ} \mathrm{S}$ & $50^{\circ} \mathrm{S}-70^{\circ} \mathrm{S}$ & $40^{\circ} \mathrm{S}-70^{\circ} \mathrm{S}$ \\
\hline $\begin{array}{l}\text { Joint atmosphere/ocean } \\
\text { inversion }\end{array}$ & [Jacobson et al., 2007] & & & & & & $-0.15 \pm 0.07^{\mathrm{a}}$ \\
\hline Atmospheric inversion & [Jacobson et al., 2007] & & & & & & $-0.63 \pm 0.6^{\mathrm{a}}$ \\
\hline $\begin{array}{l}\text { TRANSCOM-3 } \\
\text { Atmospheric inversion }\end{array}$ & [Gurney et al., 2002] & & & -0.1 & -0.3 & & \\
\hline Atmospheric inversion & [Patra et al., 2005] & & & & & -0.7 & \\
\hline Oceanic inversion & [Gloor et al., 2003] & $\sim-0.4$ & -0.1 & +0.3 & & & \\
\hline $\begin{array}{l}\text { Oceanic } \mathrm{pCO}_{2} \\
\text { climatology-NCEP } \\
10 \mathrm{~m} \text { winds }\end{array}$ & $\begin{array}{l}\text { [Takahashi et al., } \\
\text { 2002] - corrected }\end{array}$ & & & & & -0.45 to -0.35 & \\
\hline $\begin{array}{l}\text { Annual } \mathrm{pCO}_{2} \\
\text { measurements - satellite } \\
\text { winds products } \\
1992-1995\end{array}$ & [Metzl et al., 1999] & -1 & & & & & \\
\hline $\begin{array}{l}\text { Winter/summer } \mathrm{pCO}_{2} \\
\text { measurements and } \\
\text { semiprognostic model }\end{array}$ & [Metzl et al., 2006] & & & & & -0.17 & \\
\hline $\begin{array}{l}\text { Semiprognostic model } \\
\text { with some observational } \\
\text { constraints }(1984-1994)\end{array}$ & $\begin{array}{l}\text { [Louanchi and } \\
\text { Hoppema, 2000] }\end{array}$ & & & & & -0.5 to -0.8 & \\
\hline $\begin{array}{l}\text { Oceanic DIC/ALK } \\
\text { Climatology-NCEP } \\
10 \text { m winds }\end{array}$ & this study & $-1.1 \pm 0.6$ & & & & $-0.4 \pm 0.25$ & \\
\hline
\end{tabular}

${ }^{\mathrm{a}}$ South of $44^{\circ} \mathrm{S}$. 
for the circumpolar SAZ, similar to our result of $1.1 \mathrm{PgC} / \mathrm{yr}$. On further analysis, our estimate is dominated by very large fluxes with the Pacific sector of the SAZ, and as explained earlier needs further analysis to understand if this signal is realistic.

[41] Ocean circulation models also suggest that the Southern Ocean is a moderate net $\mathrm{CO}_{2}$ sink. These models imply that the Southern Ocean was a source of $\mathrm{CO}_{2}$ to the atmosphere during pre-industrial times. However, since the inception of fossil fuel derived $\mathrm{CO}_{2}$ to the atmosphere, these same models predict the Southern Ocean to contribute up to $40 \%$ of anthropogenic $\mathrm{CO}_{2}$ uptake on a global scale [Orr et $a l ., 2001]$. The natural and anthropogenic $\mathrm{CO}_{2}$ fluxes offset each other resulting in a moderate net $\mathrm{CO}_{2}$ sink. This result is supported to some degree by oceanic inversions where DIC observations are used in conjunction with ocean transport models to estimate regional $\mathrm{CO}_{2}$ fluxes of both the natural (pre-industrial) and anthropogenic components.

[42] The discrepancy between oceanic and atmospheric methodologies is not as apparent when just focusing on estimates south of $50^{\circ} \mathrm{S}$. The processes influencing $\mathrm{CO}_{2}$ uptake in the SAZ $\left(40^{\circ} \mathrm{S}-50^{\circ} \mathrm{S}\right)$ differ significantly from those that are important farther south. Gloor et al. [2003] find the Southern Ocean (south of $58^{\circ} \mathrm{S}$ ) to be a anthropogenic $\mathrm{CO}_{2}$ sink of $\sim 0.2 \mathrm{Pg} \mathrm{C} / \mathrm{yr}$ thereby offsetting the apparent natural $\mathrm{CO}_{2}$ source $(\sim 0.1 \mathrm{Pg} \mathrm{C} / \mathrm{yr})$ giving rise to a small net $\mathrm{CO}_{2}$ sink in 1990 ( $\sim 0.1 \mathrm{Pg} \mathrm{C/yr;} \mathrm{see} \mathrm{Table} \mathrm{2).} \mathrm{Jacobson} \mathrm{et} \mathrm{al.}$ [2007] conduct the first inverse analysis of $\mathrm{CO}_{2}$ sources and sinks combining ocean and atmospheric carbon observations. Using just an atmospheric inverse analysis, Jacobson et al. [2007] find the Southern Ocean (south of $44^{\circ} \mathrm{S}$ ) to be a moderate $\mathrm{CO}_{2}$ sink of approximately $0.6 \mathrm{Pg} \mathrm{C} / \mathrm{yr}$, however when including the oceanic carbon observations, the Southern Ocean sink drops to only $0.15 \mathrm{Pg} \mathrm{C} / \mathrm{yr}$. There is a definite trend to suggest the Southern Ocean (south of $50^{\circ} \mathrm{S}$ ) is a weak-moderate $\mathrm{CO}_{2}$ sink ( 0.1 to $0.4 \mathrm{Pg} \mathrm{C} / \mathrm{yr}$ ) irrespective of the atmospheric method [Gurney et al., 2002], oceanic method [Metzl et al., 2006] (also Takahashi et al. [2002] corrected flux estimates) or the latest joint atmospheric/oceanic method [Jacobson et al., 2007]. It is difficult to compare estimates within the SAZ since many methods vary their respective latitudinal bands over this range. Irrespective of this it will be important to better constrain $\mathrm{SAZ} \mathrm{CO}_{2}$ uptake in the future as it seems this is where most variability among methods lies and the fact that both $\mathrm{T} 02$ and our estimates suggest $\mathrm{CO}_{2}$ uptake dominates in the zone.

\section{Error Analysis}

\subsection{Systematic Errors}

[43] There are three issues that could lead to systematic biases in our approach. First, the extrapolation of DIC/ALK depends on the quality of the seasonal cycles in hydrographic measurements of T, S, $\mathrm{O}_{2}$ and nutrients. Although there are orders of magnitude more hydrographic measurements available than for carbon, there will still be some regional biases within the WOA01 database. In our empirical fits for both DIC and ALK, temperature/salinity are by far the most important parameters determining the seasonal variations (Table 1). The systematic errors within the WOA01 database for theses parameters will likely be small and therefore have a negligible effect in our extrapolations. There will be deficiencies especially in the nutrient database, but the impact on the DIC seasonal cycle on the larger scale is argued to be relatively small owing to the good comparison between the zonally averaged DIC extrapolations and direct DIC measurements (Figure 3). As discussed earlier, small-scale variations in the DIC, ALK and $\mathrm{pCO}_{2}$ distributions may very well be systematic biases due to inadequacies in the WOA01 database. The importance of our estimates lie in providing insights on the larger meridional scale. In time the potential systematic biases associated with the WOA01 will become smaller with the continual sampling and the updating of the oceanic database. Secondly, calculating $\mathrm{pCO}_{2}$ by assuming a $\mathrm{CO}_{2}$ dissociation constant may also introduce systematic biases within our approach. Our analysis of over 1500 measurements in the Southern Ocean show a systematic bias of about $3 \mu \mathrm{atm}$ by using the $\mathrm{CO}_{2}$ dissociation constants proposed by DM87 (Figure 4). This translates to small bias of $0.06 \mathrm{Pg} \mathrm{C} / \mathrm{yr}$, which is about $10 \%$ of our final flux estimate. Finally, the use of wind speeds and/or the chosen gas transfer relationship could also contribute to systematic biases. Although there is strong debate over the optimal combination to use for air-sea gas exchange estimates [Wanninkhof et al., 2004], we use the same formulation as T02 so as to serve as a direct comparison.

\subsection{Random Errors}

[44] The random errors associated with our methodology are quantified using a Monte-Carlo Gaussian propagation. The three main sources of uncertainty come about through uncertainty in the regression analysis for DIC/ALK and the use of $\mathrm{CO}_{2}$ dissociation constants. Assuming each is independent we explicitly calculate the $\mathrm{pCO}_{2}$ uncertainty distribution for each $1^{\circ} \times 1^{\circ}$ pixel in the Southern Ocean, with a subsequent uncertainty estimate on the air-sea $\mathrm{CO}_{2}$ flux. For the Monte Carlo trials we vary DIC and ALK randomly by \pm 8 and $\pm 10 \mu \mathrm{mol} / \mathrm{kg}$ respectively within each $1^{\circ} \times 1^{\circ}$ grid-box 1000 times to determine the uncertainty on the $\mathrm{pCO}_{2}$ distribution. Over most of the Southern Ocean the total uncertainty in calculating the surface $\mathrm{pCO}_{2}$ is about $14 \mu \mathrm{atm}$. We then perturb the wind distributions by $\pm 2 \mathrm{~m} / \mathrm{s}$ and calculate the associated uncertainty distribution on the final $\mathrm{CO}_{2}$ flux estimates at the $68 \%$ confidence levels. The final $\mathrm{CO}_{2}$ flux uncertainties range between 0.3 and $2 \mathrm{~mol} \mathrm{CO}_{2} / \mathrm{m}_{2} / \mathrm{yr}$ and are highly correlated with the wind speed distribution owing to their strong dependence in determining air-sea fluxes. Our final integrated uncertainty estimate is $\pm 0.25 \mathrm{Pg} \mathrm{C} / \mathrm{yr}$, south of $50^{\circ}$ and \pm 0.6 between $40^{\circ} \mathrm{S}$ and $50^{\circ} \mathrm{S}$.

\section{Conclusion}

[45] Historically, the sampling of Southern Ocean $\mathrm{pCO}_{2}$ has been both temporally and spatially sparse owing to the remoteness, difficulty and cost of making such measurements. Despite this and the potential biases invoked, from an oceanic perspective it has been our only means of estimating the air-sea flux of $\mathrm{CO}_{2}$ in the Southern Ocean. 
In this study we use an empirical approach to estimate the distribution of sea surface DIC, ALK and $\mathrm{pCO}_{2}$ in the Southern Ocean via standard hydrographic parameters that are not as sensitive to spatiotemporal sampling biases. Our approach however introduces uncertainty within the empirical estimations themselves and through the calculation of $\mathrm{pCO}_{2}$ via carbonate chemistry although an analysis of over 1500 measurements find this uncertainty to be relatively small. The advantage of this approach is that the uncertainty can be explicitly calculated via Monte Carlo Gaussian propagation and values used as a valuable independent database to direct $\mathrm{pCO}_{2}$ distributions. Furthermore the reconstructed surface seasonal DIC and ALK distributions could be important fields to validate ocean biogeochemical models that experienced difficulties in simulating biological limitations and colimitations especially in high-latitude HNLC regions. In calculating the air-sea flux of $\mathrm{CO}_{2}$ using our empirically derived $\mathrm{pCO}_{2}$ we have explicitly accounted for the temporal effects of anthropogenic $\mathrm{CO}_{2}$ storage and sea-ice effects on gas exchange. We estimate a Southern Ocean $\mathrm{CO}_{2}$ sink during 1995 of $0.4 \pm 0.25 \mathrm{Pg} \mathrm{C} / \mathrm{yr}$ south of $50^{\circ} \mathrm{S}$ and combining recent independent estimates implies the Southern Ocean on a global scale is a weak-moderate contemporary net $\mathrm{CO}_{2}$ sink.

[46] Acknowledgments. This study would not have been possible without the efforts of those responsible for collecting and analyzing Southern Ocean carbon parameters during WOCE and making those measurements available. B. I. M. was supported through a grant from the Australian Research Council while R. J. M. was supported through the Australian Greenhouse Office Climate Change Program. R. M. K. was supported by NOAA grants NA17RJ2612 and NA04OAR4310117. The long-term observational program OISO conducted onboard the R.S.S. Marion-Dufresne (IPEV/TAAF) is supported by three institutes in France (INSU, IPEV and IPSL). This study is also part of the national program PROOF-SOLAS France.

\section{References}

Bates, N. R., et al. (2006), Ocean carbon cycling in the Indian Ocean: 1. Spatiotemporal variability of inorganic carbon and air-sea $\mathrm{CO}_{2}$ gas exchange, Global Biogeochem. Cycles, 20, GB3020, doi:10.1029/ 2005GB002491.

Dickson, A. G. (2001), Reference materials for oceanic measurements, Oceanography, 14, 21-22.

Dickson, A. G., and F. J. Millero (1987), A comparison of the equilibriumconstants for the dissociation of carbonic-acid in seawater media, Deep Sea Res., Part A, 34, 1733-1743.

Gibson, J. A. E., and T. Trull (1999), Annual cycle of $\mathrm{fCO}_{2}$ under sea-ice and in open water in Prydz Bay, East Antarctica, Mar. Chem., 66, 187200.

GLOBALVIEW-CO2 (2003), Cooperative Atmospheric Data Integration Project - Carbon dioxide, ftp.cmdl.noaa.gov/ccg/co2/GLOBALVIEW, NOAA CMDL, Boulder, Colo.

Gloor, M., et al. (2003), A first estimate of present and preindustrial air-sea $\mathrm{CO}_{2}$ flux patterns based on ocean interior carbon measurements and models, Geophys. Res. Lett., 30(1), 1010, doi:10.1029/2002GL015594.

Goyet, C., and D. Davis (1997), Estimation of total $\mathrm{CO}_{2}$ concentration throughout the water column, Deep Sea Res., Part I, 44, 859-877.

Goyet, C., and A. Poisson (1989), New determination of carbonic-acid dissociation-constants in seawater as a function of temperature and salinity, Deep Sea Res., Part A, 36, 1635-1654.

Gurney, K. R., et al. (2002), Towards robust regional estimates of $\mathrm{CO}_{2}$ sources and sinks using atmospheric transport models, Nature, 415 , 626-630.

Hansson, I. (1973), New set of acidity constants for carbonic-acid and boric-acid in sea-water, Deep Sea Res., 20, 461-478.

Jabaud-Jan, A., et al. (2004), Interannual variability of the carbon dioxide system in the southern Indian Ocean $\left(20^{\circ} \mathrm{S}-60^{\circ} \mathrm{S}\right)$ : The impact of a warm anomaly in austral summer 1998, Global Biogeochem. Cycles, 18, GB1042, doi:10.1029/2002GB002017.
Jacobson, A. R., S. E. Mikaloff-Fletcher, N. Gruber, J. L. Sarmiento, and M. Gloor (2007), A joint atmosphere-ocean inversion for surface fluxes of carbon dioxide: 2. Regional results, Global Biogeochem. Cycles, 21, GB1020, doi:10.1029/2006GB002703.

Johnson, K. M., et al. (1998), Coulometric total carbon dioxide analysis for marine studies: Assessment of the quality of total inorganic carbon measurements made during the US Indian Ocean $\mathrm{CO}_{2}$ Survey 1994-1996, Mar. Chem., 63, 21-37.

Key, R. M., et al. (2004), A global ocean carbon climatology: Results from Global Data Analysis Project (GLODAP), Global Biogeochem. Cycles, 18(1), GB4031, doi:10.1029/2004GB002247.

Lamb, M. F., et al. (2002), Consistency and synthesis of Pacific Ocean $\mathrm{CO}_{2}$ survey data, Deep Sea Res., Part II, 49, 21-58.

Lee, K., et al. (2000a), The recommended dissociation constants for carbonic acid in seawater, Geophys. Res. Lett., 27, 229-232.

Lee, K., et al. (2000b), Global relationships of total inorganic carbon with temperature and nitrate in surface seawater, Global Biogeochem. Cycles, 14, 979-994.

Lee, K., L. T. Tong, F. J. Millero, C. L. Sabine, A. G. Dickson, C. Goyet, G.-H. Park, R. Wanninkhof, R. A. Feely, and R. M. Key (2006), Global relationships of total alkalinity with salinity and temperature in surface waters of the world's oceans, Geophys. Res. Lett., 33, L19605, doi:10.1029/2006GL027207.

Louanchi, F., and M. Hoppema (2000), Interannual variations of the Antarctic Ocean $\mathrm{CO}_{2}$ uptake from 1986 to 1994, Mar. Chem., 72, 103-114.

Louanchi, F., et al. (1996), Modelling the monthly sea surface $\mathrm{f}\left(\mathrm{CO}_{2}\right)$ fields in the Indian Ocean, Mar. Chem., 55, 265-279.

Lourey, M. J., and T. W. Trull (2001), Seasonal nutrient depletion and carbon export in the Subantarctic and Polar Frontal Zones of the Southern Ocean south of Australia, J. Geophys. Res., 106, 31,463-31,487.

Matear, R. J., and A. C. Hirst (1999), Climate change feedback on the future oceanic $\mathrm{CO}_{2}$ uptake, Tellus, Ser. B, 51, 722-733.

Matear, R. J., et al. (2003), Can CFCs be used to determine anthropogenic $\mathrm{CO}_{2}$ ?, Global Biogeochem. Cycles, 17(1), 1013, doi:10.1029/2001GB001415.

McCartney, M. S. (Ed.) (1977), Subantarctic Mode Water, pp. 103-119, Pergamon, Oxford.

McNeil, B. I., et al. (2001), Accumulation and uptake of anthropogenic $\mathrm{CO}_{2}$ in the Southern Ocean, south of Australia between 1968 and 1996, J. Geophys. Res., 106, 31,431-31,445.

McNeil, B. I., et al. (2003), Anthropogenic $\mathrm{CO}_{2}$ uptake by the ocean based on the global chlorofluorocarbon data set, Science, 299, 235-239.

Mehrbach, C., et al. (1973), Measurement of the apparent dissociation constants of carbonic acid in seawater at atmospheric pressure, Limnol. Oceanogr., 18, 897-907.

Metzl, N., et al. (1999), The annual fCO(2) cycle and the air-sea $\mathrm{CO}_{2}$ flux in the sub-Antarctic Ocean, Tellus, Ser. B, 51, 849-861.

Metzl, N., et al. (2006), Summer and winter air-sea $\mathrm{CO}_{2}$ fluxes in the Southern Ocean, Deep Sea Res., Part I, 53, 1548-1563.

Millero, F. J., et al. (1998), Distribution of alkalinity in the surface waters of the major oceans, Mar. Chem., 60, 111-130.

Millero, F. J., D. Pierrot, W. Lee, R. Wanninkhof, R. Feely, C. L. Sabine, R. M. Key, and T. Takahashi (2002), Dissociation constants for carbonic acid determined from field measurements, Deep Sea Res., Part I, 49, $1705-1723$

Nicol, S., et al. (2000), Ocean circulation off east Antarctica affects ecosystem structure and sea-ice extent, Nature, 406, 504-507.

Orr, J. C., et al. (2001), Estimates of anthropogenic carbon uptake from four three-dimensional global ocean models, Global Biogeochem. Cycles, 15, $43-60$.

Orsi, A. H., et al. (1995), On the meridional extent and fronts of the Antarctic Circumpolar Current, Deep Sea Res., Part I, 42, 641-673.

Patra, P. K., et al. (2005), Interannual and decadal changes in the sea-air $\mathrm{CO}_{2}$ flux from atmospheric $\mathrm{CO}_{2}$ inverse modeling, Global Biogeochem. Cycles, 19, GB4013, doi:10.1029/2004GB002257.

Rintoul, S. R. (1998), On the origin and influence of Adelie Land Bottom Water, in Ocean, Ice and Atmosphere, Antarct. Res. Ser., vol. 75, edited by S. S. Jacobs and R. F. Weiss, pp. 151-171, AGU, Washington, D. C.

Rintoul, S. R., and M. H. England (2002), Ekman transport dominates local air-sea fluxes in driving variability of Subantarctic Mode Water, J. Phys. Oceanogr., 32, 1308-1321.

Rintoul, S. R., and T. W. Trull (2001), Seasonal evolution of the mixed layer in the Subantarctic Zone south of Australia, J. Geophys. Res., 106, $31,447-31,462$.

Roy, R. N., et al. (1993), The dissociation constants of carbonic acid in seawater at salinities 5 to 45 and temperatures $0^{\circ}$ to $45^{\circ} \mathrm{C}$, Mar. Chem., $44,249-267$

Rubin, S. I. (2003), Carbon and nutrient cycling in the upper water column across the Polar Frontal Zone and Antarctic Circumpolar Current along 
$170^{\circ} \mathrm{W}$, Global Biogeochem. Cycles, 17(3), 1087, doi:10.1029/ 2002GB001900.

Sarmiento, J. L., et al. (2002), A new estimate of the $\mathrm{CaCO}_{3}$ to organic carbon export ratio, Global Biogeochem. Cycles, 16(4), 1107, doi:10.1029/2002GB001919.

Slansky, C. M., et al. (1996), The stepwise linear regression method for calculating anthropogenic $\mathrm{CO}_{2}$ invasion into the North Pacific, in Biogeochemical Processes in the North Pacific, edited by S. Tsunogai, Jpn. Mar. Sci. Found., Aomori, Japan.

Sweeney, C. (2003), The annual cycle of surface $\mathrm{CO}_{2}$ and $\mathrm{O}_{2}$ in the Ross Sea: A model for gas exchange on the continental shelves of Antarctica, in Biogeochemistry of the Ross Sea, Antarct. Res. Ser, vol. 78, edited by G. R. DiTullio and R. B. Dunbar, pp. 295-312, AGU, Washington, D. C Takahashi, T., et al. (2002), Global sea-air $\mathrm{CO}_{2}$ flux based on climatological surface ocean $\mathrm{pCO}(2)$, and seasonal biological and temperature effects, Deep Sea Res., Part II, 49, 1601-1622.

Trull, T. W., et al. (2001), Moored sediment trap measurements of carbon export in the Subantarctic and Polar Frontal Zones of the Southern Ocean, south of Australia, J. Geophys. Res., 106, 31,489-31,509.

Wallace, D. W. R. (1995), Monitoring global ocean inventories, 54 pp., Dev. Panel Background Rep. 5, Tex. A and M, College Station.
Wanninkhof, R. (1992), Relationship between wind speed and gas exchange over the ocean, J. Geophys. Res., 97, 7373-7382.

Wanninkhof, R., K. F. Sullivan, and Z. Top (2004), Air-sea gas transfer in the Southern Ocean, J. Geophys. Res., 109, C08S19, doi:10.1029/ 2003JC001767.

A. Corbiere and N. Metzl, LOCEAN-IPSL, UMR 7159, CNRS, Institut Pierre Simon Laplace, Universite Pierre et Marie Curie, Case 100, 4, place Jussieu, Cedex 5, F-75252 Paris, France. (corbiere@ccr.jussieu.fr; metzl@ccr.jussieu.fr)

R. M. Key, Program in Atmospheric and Ocean Sciences, Department of Geosciences, Princeton University, Princeton, NJ 08544-1003, USA. (key@princeton.edu)

R. J. Matear, Division of Marine Research, CSIRO, GPO Box 1538, Hobart, TAS 7001, Australia. (richard.matear@csiro.au)

B. I. McNeil, Climate Change Research Centre, School of Mathematics, University of New South Wales, Sydney, NSW 2052, Australia. (b.mcneil@unsw.edu.au) 